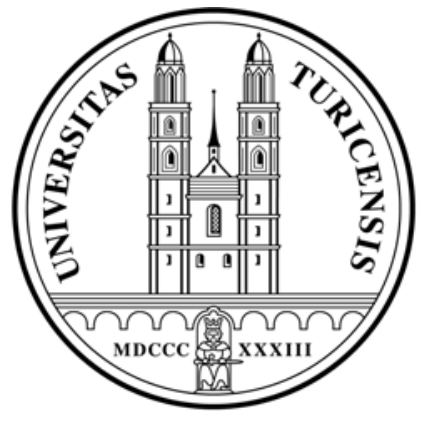

Institute for Empirical Research in Economics

University of Zurich

Working Paper Series

ISSN 1424-0459

Working Paper No. 464

Legal Enforcement, Public Supply of Liquidity and Sovereign Risk

Filippo Brutti

January 2010 


\title{
Legal Enforcement, Public Supply of Liquidity and Sovereign Risk
}

\author{
Filippo Brutti* \\ University of Zurich and Study Center Gerzensee
}

\begin{abstract}
Sovereign debt crises in emerging markets are usually associated with liquidity and banking crises within the economy. This connection is suggested by both anecdotical and empirical evidence. The conventional view is that the domestic financial turmoil is caused by foreign creditors' retaliation. Yet, there is no clear-cut evidence supporting the existence of "classic" default penalties (e.g., trade sanctions or exclusion from international capital markets). This paper then proposes a novel mechanism linking sovereign defaults with liquidity and banking crises without any intervention of foreign creditors. The model considers a standard unwillingness-to-pay problem assuming that: (i) the enforcement of private contracts is limited and, as a result, public debt represents a source of liquidity; (ii) the government cannot discriminate between domestic and foreign agents. In this setting, the prospect of drying up the private sector's liquidity restores the ex-post incentive to pay of the government without any need to assume foreign penalties. Nonetheless, liquidity crises might arise when economic conditions deteriorate and the government chooses opportunistically to default in order to avoid the repayment of foreign agents. The interaction between the enforcement friction and sovereign risk is then exploited to study the implications on international capital flows and legal and institutional domestic reforms.
\end{abstract}

Keywords: Legal institutions, liquidity, sovereign risk, financial dependence.

JEL Classification: F34, O16.

${ }^{*}$ I thank Jaume Ventura for his valuable guidance and countless suggestions, as well as Fernando Broner, Paula Bustos, Davide Debortoli, José Antonio Dorich, Nathan Foley-Fisher, Gino Gancia, Nicola Gennaioli and Joachim Voth, Vivian Yue for helpful comments. I am particularly indebted with Alberto Martin for discussing with me the idea of the paper since the very beginning. I also thank International Breakfast Seminar's participants at Universitat Pompeu Fabra and "Micro and Macroeconomic Effects of Financial Globalization" Conference at NBER. Any remaining errors are my own. Financial support from the European Research Council (ERC Advanced Grant IPCDP-229883) is gratefully acknowledged. Correspondence: brutti@iew.uzh.ch. 


\section{Introduction}

A long-standing question in the sovereign debt literature concerns the identification of the costs associated with default. Given that sovereigns cannot be forced to honor their obligations under existing legal arrangements (due to the jurisprudential principle of "sovereign immunity"), the literature coincides on that the mechanism making sovereign debt possible is that countries repay their debt to avoid the costs of default. There is no doubt, indeed, that default represents an unappealing policy option for governments, which might precipitate the economy into protracted growth slowdown and financial turmoil. Nevertheless, there is much less agreement on which mechanism generates such negative outcomes. Typically, past studies have focused on "external" cost channels as trade sanctions, borrowing restrictions or reputational issues, ${ }^{1}$ but there is no clear-cut evidence supporting the existence of these classic penalties. ${ }^{2}$ My analysis, instead, takes an inward perspective and proposes a novel mechanism linking sovereign defaults with liquidity and banking crises without any intervention of foreign creditors.

This paper is motivated by both anecdotical and empirical evidence suggesting that sovereign debt crises in emerging markets are usually associated with liquidity crises and banking crises within the economy. For example, during the Argentine crisis in 2001-2002, the temporary suspension of debt payments by the government concurred to undermine the strength of banks' balance sheets. With banks not granting new loans, businesses dramatically cut back on their spending, aggravating further the economic downturn. ${ }^{3}$ Such a "domino effect" might be a latent threat in many emerging markets, where domestic financial institutions, in particular commercial banks, are major holders of public debt. ${ }^{4}$ As a matter of fact, Borensztein and Panizza (2008) show that over the period 1980-2000 sovereign defaults often predicted banking crises in a wide sample of emerging economies. ${ }^{5}$

In order to explain the connection between sovereign defaults and liquidity and banking crises, this paper studies a standard unwillingness-to-pay problem in a setting where: (i) domestic firms save (either directly or indirectly through the banking sector) in government bonds, which are stored as a reserve of liquidity to finance a reinvestment made necessary by an unexpected shock; (ii) the government cannot discriminate between domestic and foreign bondholders. As a con-

\footnotetext{
${ }^{1}$ See Sturzenegger and Zettelmeyer (2006) for a state of the art review of the literature.

${ }^{2}$ Though, the academic debate on the identification of these "classic" penalties is alive and well. Borensztein and Panizza (2008) review past empirical studies on the cost of defaults.

${ }^{3}$ A similar analysis is made by Mishkin (2006), as reported in the appendix.

${ }^{4}$ Kumhof and Tanner (2005) report that financial institutions' net credit to the government relative to their total assets ranges from $20 \%$ to $40 \%$ in emerging markets, whereas this ratio is typically around $10 \%$ in advanced countries.

${ }^{5}$ Applying a methodology similar to Kaminsky and Reinhart (1999) to a large sample of countries over 19752000 , these authors find that the probability of a banking crisis in a given year conditional on having a sovereign default in the same year or in the year before is 14 percent, whereas the unconditional probability is only a 2 percent, and the difference between the conditional and unconditional probability is statistically significant. On the other hand, the probability of a sovereign default conditional on a banking crisis is not statistically different from the unconditional probability. This evidence then suggests that sovereign defaults might lead to banking crises, while the contrary is on average not true.
} 
sequence of these two assumptions, the government faces a trade-off when choosing whether to fulfill its debt obligations. Indeed, debt repayment implicitly transfers resources from domestic taxpayers to both domestic bond holders (domestic firms) and foreign bond holders. The transfer to domestic bond holders involves only a redistribution within the economy. When the government does not care about wealth inequality, such a transfer unambiguously raises domestic welfare since it enhances liquidity provision in the economy. On the other hand, the transfer to foreign bond holders involves a redistribution of resources away from the economy. Given that the government does not care about foreigners, such a transfer reduces domestic welfare.

More specifically, the model considers a small open economy that has scarce initial resources, limited legal enforcement and suffers from a lack of collateral which limits the private provision of liquidity (i.e., easily tradable financial securities). Domestic firms face the risk of adverse shocks, that require an additional investment along the production process, and need to store precautionary savings. Given that there is under-supply of private securities and no exogenous storage technology, domestic firms save in government bonds. At the same time, the government issues a public bond to both domestic and foreign agents in order to undertake a public investment project. In addition, the government is a sovereign which cannot credibly commit to honor its future obligations and cares only about domestic agents. The standard unwillingness-to-pay problem then arises as the government has an ex-post incentive to avoid the repayment of foreign creditors. Yet, assuming that the government cannot discriminate between domestic and foreign bond holders, the repudiation of debt produces a loss of aggregate output as domestic firms cannot reinvest in their projects. My model then shows that the prospect of drying up the private sector's liquidity restores the ex-post incentive to pay of the government without any need to assume foreign penalties.

In this setting, a liquidity crisis arises when the economy experiences an adverse shock (either an aggregate productivity shock or a terms-of-trade shock). However, the crisis is not triggered by either currency or maturity mismatches in the government's fiscal balance, as supposed in past studies, ${ }^{6}$ but it is a consequence of the opportunistic behavior of the government. As the aggregate shock lowers the returns of domestic firms on additional investment, the social cost implied by a liquidity crisis falls below the fiscal cost required to repay the debt and so the government announces the default. In particular, the model suggests that the occurrence of liquidity crises induced by sovereign default is particularly likely in economies characterized by pronounced business cycle volatility.

By highlighting a direct mechanism through which a sovereign default imposes a cost on the domestic economy, my paper contributes to the sovereign debt literature. Since the seminal contribution of Eaton and Gersovitz (1981), the conventional view in the literature has been that default represents an unappealing policy option for governments since it either triggers foreign

\footnotetext{
${ }^{6}$ In particular, in the Original Sin literature, as surveyed in Eichengreen et al. (2003), or in Chang and Velasco (1999).
} 
retaliation, and thus exerts a negative effect on domestic production and financial activity, or has reputational consequences. ${ }^{7}$ Only recently, and in part as a side effect of the financial turmoil caused by the latest default episodes, more attention has been paid on direct effects on the domestic economy. Notable contributions in this sense are Sandleris (2006) and Broner and Ventura (2006, 2008). In particular, my paper is closely related to Broner and Ventura (2006, 2008) in assuming that the government cannot discriminate between domestic and foreign agents. Different implications are however obtained. In the framework considered by these authors, sovereign default leads to an undesirable redistribution of resources within the economy. In my model, instead, sovereign default leads to a disruption of private investment.

My paper is also related to the work of Woodford (1990) and, in particular, Holmstrom and Tirole (1998). These authors show that a credible and benevolent government can enhance private liquidity provision by issuing a public bond. Indeed, the government can expand the supply of liquidity (i.e., easily tradable financial securities) thanks to its assumed ability to commit agents' future income through taxation. ${ }^{8}$ Nevertheless, Holmstrom and Tirole's argument depends crucially on the assumption that the economy is closed, and so domestic firms cannot store liquidity by saving abroad. Indeed, when there are no restrictions on international capital flows and the government commits to repay in the future, the interest rate on government bond is set by the world interest rate and entrepreneurs are indifferent between saving in the domestic public debt or saving abroad. In other words, international capital markets provide the economy with sufficient supply of liquidity and reduce the need for government intervention. Nevertheless, my model shows that Holmstrom and Tirole's argument can be restored in an open economy setting by simply relaxing the assumption of credible government commitment considered by these authors. In particular, it is possible to show that the absence of commitment generates a contingent repayment policy by the government and, as a result, government debt becomes an imperfectly substitutable source of liquidity for the economy.

Finally, by relaxing the perfect commitment assumption, it is also possible to study in a non trivial way the incentive of the government to improve domestic regulation. In particular, a better rule of law induces a substitution between precautionary savings in non-contingent government bonds to contingent forms of insurance. Yet, as domestic firms don't need anymore to save in government bond, the sovereign risk problem reappears restricting the government's access to foreign lending. My model then describes the economic conditions that lead the government to improve regulation. In particular, it is shown that the government's incentive to undertake

\footnotetext{
${ }^{7}$ See in addition, Grossman and Van Huyck (1988), Bulow and Rogoff (1989), Fernandez and Rosenthal (1990), Cole and Kehoe (1998), Kletzer and Wright (2000), Wright (2002), Amador (2004), Yue (2005), Aguiar and Gopinath (2006) and Arellano (2008), among others. See Eaton and Fernández (1995) and Sturzenegger and Zettelmeyer (2006) for two excellent surveys of the sovereign debt literature.

${ }^{8}$ The issue of optimal liquidity provision has been extensively analyzed by past literature. A partial list of past contributions include Reinhart et al. (2000),Allen and Gale (2004), Kumhof (2004), Taddei (2004), Gorton and Huang (2004), Caballero and Krishnamurthy (2008). In particular, Caballero and Krishnamurthy (2008) push this argument farther and show that the government intervention can also improve efficiency in the use of private collateral.
} 
a legal reform is positively related to the average return on private investment and negatively to the return on public investment. The model then suggests a possible explanation for crosscountry and cross-time variation in legal institutions which differs from studies stressing political economy issues, as for example Rajan and Zingales (2003) and references therein.

The rest of the paper is organized as follows. Section 2 describes a baseline model of government debt as a source of liquidity. Section 3 introduces sovereign risk in this setup and analyzes the mechanism leading to liquidity crises. Section 4 discusses the model implications on institutional and political reforms. Section 5 presents a cross-country, cross-industry evidence that is suggestive of the mechanism emphasized by the paper. Finally, section 6 concludes.

\section{A model of government debt as a source of liquidity}

In this section I set up the environment of the economy. The model highlights: (i) the problem of domestic entrepreneurs (firms), who start a long-term investment facing the risk of a shock on total costs (expenditure shock) before completion; (ii) the problem of a benevolent government, who chooses public debt issuance in order to finance a public investment project. As a consequence of capital market imperfections, domestic firms save in government bonds to hoard a reserve of liquidity against the future shock. This setup will be enriched by introducing sovereign risk in section 3 , in order to study the connection between sovereign default and liquidity and banking crises.

\subsection{Environment}

Consider a small open economy lasting for three periods: $t=0,1,2$. In this economy there are only two goods: a private good, that can be used for consumption and investment, and a public good, that can be used only for cosumption. The economy is inhabited by three types of agents: a continuum (with mass one) of entrepreneurs, a continuum (with mass one) of workers and a government. Both entrepreneurs and workers are competitive and risk neutral, consume only at date 2 and their preferences are described by the utility function $U=c+v(g)$, where $c$ denotes the consumption of the private good, $g$ denotes the consumption of the public good and the function $v(\cdot)$ satisfies the Inada conditions. In addition to the three domestic agents, there is an international financial market (IFM) which can lend to or borrow from the country with no restrictions. The IFM is competitive, risk-neutral, deep-pocketed, has access to an investment/saving technology with rate of return $r=1$ and can perfectly commit to repay in the future.

Let's first characterize the technology and the agents of this economy. The entrepreneurs are born with no endowment but have access to a private production technology. The private technology 
is represented by a continuum of investment projects $j$ operated within individual firms. Projects have decreasing returns to scale and are subject to two independent shocks, which are observed at date 1: (i) an aggregate shock, which affects all projects in the same measure, and (ii) an idiosyncratic shock, which affects each project individually. In particular, investment $k$ in each project costs $k$ units of the private good at date 0 and delivers a final output $f_{s, j}(k)$ at date 2 , where

$$
f_{s, j}(k)=\left\{\begin{array}{ll}
\theta_{s} A_{j} k & \text { if } k \leq \bar{k} \\
\theta_{s} A_{j} \bar{k} & \text { if } k>\bar{k}
\end{array},\right.
$$

$\theta_{s}$ denotes the aggregate shock which depends on the state of the economy $s$ and $A_{j}$ denotes the idiosyncratic shocks which is specific to each project $j$.

The production technology then features stepwise decreasing returns to scale, i.e. the marginal return on capital is positive (and constant) up to the upper bound $\bar{k}$ and zero afterwards. This assumption reflects either the existence of indivisibility in physical capital, i.e. machinery, plants, buildings, or bounded organizational capacity that limits the scope of each entrepreneur's investment. Notice that the main results of the paper would go through even if the production technology were described by a continuously differentiable production function with decreasing returns to scale. Yet, assuming a production function like (1) permits to pin-point the aspects of the economy that are crucial for the results of the paper, as discussed with more detail later on.

The aggregate shock $\theta_{s}$ reflects all sorts of events that exert a common effect on all firms in the economy, e.g. improvements in total factor productivity, fluctuations in the terms of trade, fiscal and economic reforms or changes in the supply of human capital. For the sake of clarity, I henceforth refer to the aggregate shock as a "productivity" shock and I assume that there are only two states of the economy, called "good state" and "bad state". In particular, the aggregate productivity equals $\bar{\theta}>1$ in the good state and $\underline{\theta}<1$ in the bad state. Let $\pi(\bar{\theta}) \in[0,1]$ be the probability of the good state and let $\pi(\underline{\theta})=1-\pi(\bar{\theta})$ be the probability of the bad state. Lastly, the aggregate shock is normalized to one in expected terms, i.e. $\sum_{\theta_{s} \in\{\bar{\theta}, \underline{\theta}\}} \pi\left(\theta_{s}\right) \theta_{s}=1$.

The idiosyncratic shock $A_{j}$ reflects, instead, those events that exert a localized effect on each firm or sector. As a particular feature of the idiosyncratic shock, I consider that this shock requires an additional investment by the entrepreneur that receives it. Suitable examples for the idiosyncratic shock include machinery substitution, industry-specific technology upgrades, sales recalling due to product imperfections, sudden interruption of supply contracts. The idiosyncratic shock is hereby termed "expenditure" shock. Suppose that the shock takes only two realizations, i.e. one half of the firms is "lucky" and does not get the shock while the remaining half is "unlucky" and gets the shock. Ex-ante all firms are equally likely to be lucky or unlucky. The expenditure shock causes a decline in firm productivity, which can be offset by an additional investment $i$. In 
particular, when the firm is lucky, $A_{j}=A$ and final output is $\theta_{s} A k$. On the other hand, when the firm is unlucky, $A_{j}=a$ and final output is $\theta_{s}(a k+(A-a) i)$, with $i \leq k$ given that the additional investment can at most restore the ex-ante productivity. Recall now that the aggregate and the idiosyncratic shock are independent and that the aggregate shock is normalized to one in expected terms. Then, setting $\frac{A+a}{2}>1$, the expected return on the initial investment $k$ is positive. In addition, setting $\underline{\theta}(A-a)>1$, the return on the additional investment $i$ is also positive. Figure 1 describes the timing of private investment projects.

Figure 1: Timing of Investment Projects

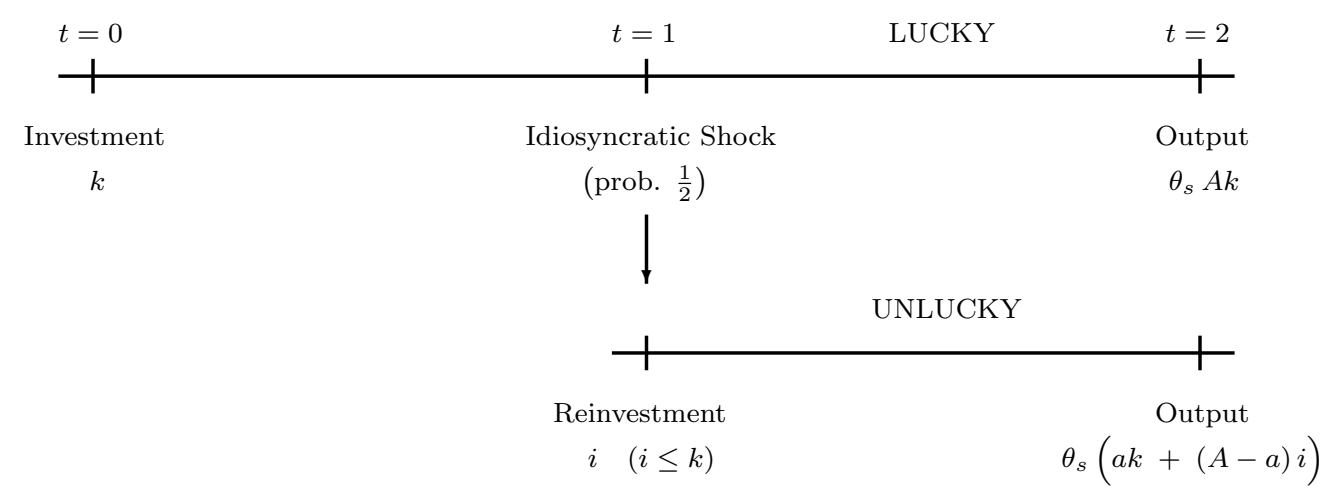

The workers have no initial endowment as entrepreneurs, they don't have access to the private investment technology but they can work at date 1 obtaining a wage $w$. The labor income is then saved until date 2, when workers retire and consume their wealth. The source of workers' wage is not explicitly determined, as it does not represent a crucial feature for the results of the model. $^{9}$

The government maximizes the average utility of domestic agents and has access to a public investment technology. In particular, by investing $g$ units of the private good, it can provide a public good from which domestic agents obtain utility $v(g)$ at date 2. Furthermore, the government can issue a non-contingent bond (either short-term or long-term) to both domestic and foreign agents and can collect lump-sum taxes from domestic agents at any date.

In conclusion, the economy has no initial endowment and has positive returns on both private and public investment. As a result, the economy needs to borrow from the IFM in order to reap the benefits from investment. In particular, at date 0 entrepreneurs borrow the resources necessary to start their investment projects by issuing a set of claims (equities) which assign to each holder an ownership right on a unit share of future production. In addition, the government

\footnotetext{
${ }^{9}$ Yet, it is possible to consider that workers supply their labor force to entrepreneurs and receive a remuneration along the production process.
} 
finances the public project by issuing a public bond at date 0 , which is repaid by collecting taxes from domestic agents either at date 1 or at date 2 (depending on the maturity structure of the initial bond issuance).

\section{$2.2 \quad$ Financial frictions}

The economy's access to foreign credit is, however, restricted by weak legal and political domestic institutions. Suppose either that the scope of financial regulation is somewhat bounded or that courts' effectiveness in enforcing private contracts is limited by flaws in judicial procedures or pervasive corruption of public officers. In all of these circumstances, the economy would suffer from a lack of private collateral which restricts agents' ability to borrow from outside investors. The following assumption provides a formal description of the legal frictions in this economy.

Assumption 1 Domestic entrepreneurs can pledge as collateral only a fraction $\gamma$ of projects' output, while workers cannot pledge their future labor income.

Arguably, Assumption 1 resembles the legal environment of an emerging economy characterized by poor regulation and/or weak enforcement of private financial contracts. This assumption has crucial consequences in the environment so far described. In particular, entrepreneurs, despite being risk-neutral, have an incentive to insure against the idiosyncratic shock in order to avoid a pitfall in the expected revenue from the project. Indeed, when $\gamma \frac{A+a}{2}>1$ and $\gamma \bar{\theta}(A-a)<1$, the initial investment $k$ is profitable for both domestic entrepreneurs and the IFM but the additional investment $i$ is profitable only for the former. Therefore, unlucky entrepreneurs cannot borrow in the spot market at date 1 and are forced to abandon the profitable reinvestment.

Clearly, entrepreneurs could efficiently insure against the idiosyncratic shock by underwriting a contingent contract with the IFM, which promises a positive transfer when the firm is unlucky in exchange for a positive payment when the firm is lucky. Yet, in this economy there is no such private insurance.

Assumption 2 Domestic entrepreneurs cannot enter into contracts that are contingent on the expenditure shock.

This assumption can be justified arguing that poor regulation and ineffective monitoring favor firms' moral hazard and, consequently, limit their ability to get insurance. However, an in-depth discussion of the factors that affect insurance provision is beyond the scope of the paper, and Assumption 2 is taken as a description of a missing market in the economy. Absent contingent 
contracts and given that borrowing at date 1 is not possible, the only alternative open to entrepreneurs to buffer future shocks is to accumulate reserves of non-contingent securities, which can be deployed in case of need.

Notice, however, that a benevolent government which seeks to maximize domestic social welfare and is able to costlessly reallocate resources among domestic agents could design a contingent redistribution scheme transferring resources from workers and lucky entrepreneurs to unlucky entrepreneurs. By doing so, the government could substitute the private provision of insurance fostering the additional investment in distressed projects. Nonetheless, the following assumption restricts the government from making such transfers.

Assumption 3 The government cannot make positive transfers between domestic agents.

In the following section, I characterize the equilibrium for this economy assuming that agents are fully rational and there is no asymmetric information, i.e. both types of shocks are perfectly observable by all agents. In addition, I first consider a benchmark case where the government has a good reputation and is fully credible.

Assumption 4 The government can credibly commit to fulfill its debt obligations.

The analysis of this particular case, where there is no risk of default on government bonds, serves a purely illustrative purpose. Indeed, section 3 will show that, in the environment so far described, the occurrence of a liquidity crisis can be accounted for by relaxing exclusively Assumption 4.

\subsection{Equilibrium with government commitment}

At date 0 the representative entrepreneur borrows an amount $k+b+f$ by issuing equities to the IFM, where $k$ is the initial investment in the project, $b$ is the saving in government bonds and $f$ is the saving in foreign bonds. At date 1 the entrepreneur can either be lucky or unlucky. In the former case, the project requires no additional spending and the entrepreneur rolls over his bond holdings $b$ and $f$ until date 2 . In the latter case, the project receives the expenditure shock and the entrepreneur deploys his saving in order to invest $i$ additional units of the private good in the project. Finally, his final output is $y_{l}\left(\theta_{s}\right)$ if he has been lucky and $y_{u}\left(\theta_{s}\right)$ if he has been unlucky, where

$$
y_{l}\left(\theta_{s}\right)=\theta_{s} A k+b+f \quad \text { and } \quad y_{u}\left(\theta_{s}\right)=\theta_{s}(a k+(A-a) i)+b+f-i
$$

provided the initial investment $k$ does not exceed the upper bound $\bar{k}$. In this case, indeed, the marginal return on $k$ would be equal to zero in each contingency. Yet, we can dismiss this 
possibility as the entrepreneur invests at most $\bar{k}$ to maximize the net return from the project. Having obtained the final output from the project, the entrepreneur pays foreign shareholders by distributing dividends, which must be lower or equal than the firm's collateral and are respectively $r_{l}\left(\theta_{s}\right)(k+b+f) \leq \gamma y_{l}\left(\theta_{s}\right)$ and $r_{u}\left(\theta_{s}\right)(k+b+f) \leq \gamma y_{u}\left(\theta_{s}\right)$. Recall that the IFM is competitive and risk neutral. Therefore, the IFM accepts to enter only in loan contracts that offer a nonnegative return, i.e. $\sum_{\theta_{s} \in\{\bar{\theta}, \underline{\theta}\}} \pi\left(\theta_{s}\right)\left[\frac{r_{l}\left(\theta_{s}\right)+r_{u}\left(\theta_{s}\right)}{2}\right] \geq 1$. Lastly, notice that I implicitly assumed that the representative entrepreneur does not pay taxes. This assumption implies no loss of generality, as discussed with more detail when I describe the government's problem. Indeed, in equilibrium the government does not tax entrepreneurs in order to preserve the net reserves of liquidity of domestic firms and maximize their reinvestment.

Absent any borrowing constraint, the entrepreneur would choose the initial investment $k$, the saving in government bonds $b$ and in foreign bonds $f$, and the additional investment $i$ to maximize the expected revenue from the project, as in

$$
\Pi=\max _{k, i, b, f} \sum_{\theta_{s} \in\{\bar{\theta}, \underline{\theta}\}} \pi\left(\theta_{s}\right)\left[\frac{y_{l}\left(\theta_{s}\right)-r_{l}\left(\theta_{s}\right)(k+b+f)}{2}+\frac{y_{u}\left(\theta_{s}\right)-r_{u}\left(\theta_{s}\right)(k+b+f)}{2}\right]
$$

subject to the maximum reinvestment constraint, $i \leq k$, the resource constraint at date 1 , $i \leq b+f$, where $b \geq 0$ and $f \geq 0$, and the non-negative profit constraint on IFM's loans,

$$
\sum_{\theta_{s} \in\{\bar{\theta}, \underline{\theta}\}} \pi\left(\theta_{s}\right)\left[\frac{r_{l}\left(\theta_{s}\right)+r_{u}\left(\theta_{s}\right)}{2}\right] \geq 1 .
$$

However, as firm's collateral is limited, the entrepreneur choice is also subject to the borrowing constraints,

$$
r_{l}\left(\theta_{s}\right)(k+b+f) \leq \gamma y_{l}\left(\theta_{s}\right) \text { and } r_{u}\left(\theta_{s}\right)(k+b+f) \leq \gamma y_{u}\left(\theta_{s}\right)
$$

where the firm collateral includes both the value of production and the final bond holdings. The problem of the entrepreneur then consists in choosing $\{k, i, b, f\}$ in order to maximize (3) subject to (4) and (5) plus the maximum reinvestment constraint $i \leq k$ and the intermediate period resource constraint $i \leq b+f$, where $b \geq 0, f \geq 0$.

As long as $k \leq \bar{k}$, the expected marginal return on initial investment $k$ is positive, i.e. $\frac{A+a}{2}>1$, and the entrepreneur has an incentive to raise initial investment up to $\bar{k} \cdot{ }^{10}$ Yet, the entrepreneur can borrow the resources necessary to start the project only when he can credibly promise a non-negative interest rate (in expected terms) to the IFM, i.e. $\gamma\left[\frac{A+a}{2}\right] \geq 1$. This represents the first condition on the parameter $\gamma$.

\footnotetext{
${ }^{10}$ Notice that the aggregate shock is omitted as the two shocks (aggregate and idiosyncratic) are independent and the aggregate shock has been normalized to one.
} 
Recall now that $\underline{\theta}(A-a)>1$ and suppose that $\gamma \bar{\theta}(A-a)<1$. As discussed before, these two conditions make the additional investment $i$ profitable for the entrepreneur but not for the IFM. Then, an unlucky entrepreneur cannot borrow resources in the spot credit market at date 1 and can only reinvest by deploying his saving in the government and foreign bonds. In particular, the entrepreneur will use all his reserves of bonds to maximize the profitable reinvestment and $i=b+f$. As the case of interest is $i<k$, I impose a further condition on the parameter $\gamma$ to ensure that the maximum reinvestment constraint is never binding and it can be omitted. The above restrictions are summarized by the following technical assumption.

\section{Technical assumption 1}

The parameter $\gamma$ and $\bar{\theta}$ satisfy the following conditions:

(i) $\gamma>\frac{1}{\frac{A+a}{2}}$, (ii) $\gamma<\frac{2}{\frac{A+a}{2}+\frac{1}{2}[1+(A-a)]}$, (iii) $\bar{\theta}<\frac{1}{\bar{\gamma}(A-a)}$.

Maximization of program (3)-(5) implies the following optimal investment and saving decisions,

$$
k=\bar{k} \quad \text { and } \quad b+f=\frac{\gamma \frac{A+a}{2}-1}{1-\gamma \frac{1}{2}[1+(A-a)]} \bar{k} .
$$

The first condition takes into account that the entrepreneur wants to maximize the expected return on initial investment. The second condition is obtained from the borrowing constraint (5). It is easy to see that the government bond and the foreign bond are perfect substitutes and the firm is indifferent between saving at home or saving abroad. Yet, this result depends crucially on the assumption that the government can credibly commit to repay in the future, in which case the interest rate on government bonds is set by the world interest rate. In the next section, instead, this assumption will be relaxed and it will be shown that the firm will be no more indifferent between the two types of bonds.

Notice also that the lack of collateral does not affect the initial investment of the firm, which is set at its first-best level. On the contrary, it limits the amount of liquidity, i.e. government and foreign bonds, that can be stored and used by firms to finance the intermediate reinvestment. ${ }^{11}$ This result is driven by the stepwise marginal return structure imposed on the production function and could be easily avoided by considering a more general production technology. It is, however, well known that the presence of capital market imperfections affects firms' investment choices, reducing the stock of capital available for production. ${ }^{12}$ For this reason, the model has

\footnotetext{
${ }^{11}$ In particular, this result depends on the assumption that the marginal return on initial investment is constant and positive for both entrepreneurs and outside investors, i.e. the IFM. Yet, the intermediate reinvestment is profitable for entrepreneurs but it reduces the amount of collateral that outside investors can seize from unlucky firms.

${ }^{12}$ Since the seminal contribution of Modigliani and Miller (1958), scholars have been aware that the presence of financial frictions affects the capital structure of private companies and distorts their investment choices. Hubbard
} 
been designed in a way that the presence of borrowing constraints affects exclusively firms' need for liquidity and the size of precautionary reserves. Indeed, the results obtained in the central section of the paper, section 3, arise exclusively from the interaction between firms' need for liquidity and the government's inability to commit.

Consider now the problem of the benevolent government, which has to choose public investment, debt issuance and individual taxation in order to maximizes the average utility of domestic agents. The economy has no initial endowment and, therefore, the government must finance the public investment $g$ by issuing debt. As domestic entrepreneurs are treated as first comers by the government and workers cannot buy public bonds, ${ }^{13}$ at the end of date 0 the level of domestic debt is $b$ and the level of external debt is equal to $b^{*}=g-b$.

Before solving the government's problem, it is convenient to examine the maturity structure of public debt. As domestic entrepreneurs and the IFM are indifferent between buying short-term or long-term debt ${ }^{14}$ the government can arbitrarily choose to issue one-period bonds or twoperiods bonds. Furthermore, provided the government taxes only workers at date 1 (while it can indifferently tax entrepreneurs' profits and workers' savings at date 2), the lump-sum taxation is non-distortionary. ${ }^{15}$ Therefore, Ricardian Equivalence holds and the government is indifferent between issuing short or long term debt (as explained in the next section, this result depends crucially on the government's ability to commit). Without loss of generality, I then consider that the government issues only short-term debt and repays it by collecting taxes on domestic workers at date 1 .

The objective function of the government, or social welfare function, is then given by

$$
W=\Pi+w+v(g)-\tau
$$

where $\Pi$ is the expected revenue of entrepreneurs, $w$ is the labor income of workers, $v(g)$ is the average utility of domestic agents from the public investment $g$ and $\tau$ is the taxation on workers

(1998) and Stein (2003) provide two excellent reviews of the economic literature studying the effects of capital market imperfections on corporate investment. Past research has also shown that a number of macroeconomic consequences can arise from the presence of borrowing constraints at the corporate level. A necessarily incomplete list of past contributions include: studies that show that financial frictions generate credit cycles and amplify aggregate volatility, e.g. Bernanke and Gertler (1989), Bernanke et al. (1999), Kiyotaki and Moore (1997), Carlstrom and Fuerst (1997), Kocherlakota (2000), Martin (2005); studies that show that financial frictions generate divergence in cross-country wealth distribution, in cross-country or current account balances, respectively Matsuyama (2004) and Caballero et al. (2008); studies that show that financial instability and sudden stops in capital inflows in emerging markets are exacerbated by collateral constraints, e.g. Aghion et al. (2004), Caballero and Krishnamurthy (2001), ?, Mendoza (2006).

${ }^{13}$ Indeed, domestic workers have no wealth at date 0 and cannot borrow as they have no collateral.

${ }^{14}$ At date 1 domestic entrepreneurs could indeed pledge as collateral their holdings of long-term bonds in order to get the same amount of liquidity that they could have obtained from the government as a repayment of the short-term debt. In addition, the IFM is indifferent between short-term and long-term debt by construction.

${ }^{15} \mathrm{On}$ the other hand, taxation on entrepreneurs at date 1 lowers the reserves of liquidity and the profitable investment of unlucky firms and therefore generates a social dead-weight loss. 
at date 1 . The government's budget constraint is defined by,

$$
g=b+b^{*} \quad \text { and } \quad \tau=b+b^{*} .
$$

Social welfare maximization then implies the following optimality condition for public investment,

$$
v^{\prime}(g)=1
$$

Finally, when the first-best public investment is lower or equal than the total saving of domestic entrepreneurs, i.e. $g \leq b+f$, there exists at least one equilibrium in which the government can finance the public good by issuing only domestic debt. In the alternative case, i.e. $g>b+f$, public bonds issuance exceeds the total saving of domestic entrepreneurs and the government needs to borrow from abroad. In the rest of the paper, this second situation would represent the case of interest.

\subsection{Discussion}

Holmstrom and Tirole (1998), and Woodford (1990), argued that government debt enhances private liquidity provision when there is a lack of collateral in the economy. Their intuition can be summarized as follows. When workers cannot commit to grant a credit line to domestic firms (e.g. financial intermediaries have no adequate credibility), the government can implicitly commit future taxpayers (the workers) to transfer resources to bondholders (the entrepreneurs). In addition, Holmstrom and Tirole show that the government intervention is welfare improving even in the presence of a domestic financial market for firm equities. Indeed, the shortage of collateral creates an under-supply of private securities in the economy and, thus, poses a limit on the saving capacity of firms. On the contrary, the government, thanks to its assumed ability to commit workers' income through taxation, can expand the supply of financial assets above the value of private collateral.

Anecdotical evidence gives support to this argument. For example, Reinhart et al. (2003) and Kumhof and Tanner (2005) observe that in many developing countries banks hold large reserves of public debt (relatively to their net assets), which is then used as collateral in private financial transactions. In particular, Kumhof and Tanner (2005) show that the ratio of banks' claims on the government over their net assets is negatively correlated with an index of creditors right protection. It is also well known that turnover ratios in secondary markets for government securities (in particular repo markets) have a greater order of magnitude than in private financial markets, particularly in many emerging markets (see de la Torre and Schmukler (2004)). Furthermore, although the theoretical underpinning for government-supplied liquidity is stronger in emerging markets, it can be argued that government debt also enhances the liquidity of more structured 
financial markets, as shown by the policy discussion on the consequences of the US Treasury debt paydown in late 90s (see Reinhart et al. (2000)).

It must be remarked that Holmstrom and Tirole's argument depends crucially on the assumption that domestic firms cannot store liquidity by saving abroad. When there are no restrictions on international capital flows and no sovereign risk, the interest rate on government bonds is set by the world interest rate and entrepreneurs are indifferent between saving in the domestic public debt or saving abroad. In other words, the IFM provides the economy with sufficient supply of liquidity and reduces the need for government intervention. The following section, however, shows that, by relaxing the government commitment assumption in the same setup as before, Holmstrom and Tirole's argument can be restored in an open economy setting: as government repayment becomes contingent on the state of the economy, public debt then represents an imperfectly substitutable source of liquidity for the domestic private sector. Nonetheless, the optimal fiscal policy of the government has a downside, as it exposes the economy to costly liquidity crises.

\section{Sovereign risk and liquidity crises}

In the previous section the government could perfectly commit to honor its obligations in the future. Then, it could efficiently manage public debt to lessen domestic financial inefficiencies and borrow foreign resources to undertake the public investment. Yet, the long history of sovereign defaults in emerging markets suggests that the government commitment is, at least, not fully credible. In the same setup as before, I then relax the assumption of government commitment (Assumption 4) and I discuss the implications that derive from the interaction between domestic financial frictions and sovereign risk. In particular, I show that a sovereign default triggers a liquidity crisis within the economy and that government debt represents an imperfectly substitutable source of liquidity for the private sector.

Assumption 5 The government cannot commit to service its debt and creditors cannot enforce the government repayment.

The absence of commitment introduces a classic unwillingness-to-pay problem. Ex-post the government does not want to repay its debt with the IFM as this reduces the average utility of domestic agents. Given that the IFM foresees the risk of future opportunistic behavior, it doesn't want to lend ex-ante and the government cannot borrow from abroad. Conventional models in the sovereign debt literature usually restore the ex-post incentive to repay by introducing either a default penalty or a reputational cost when a default occurs. These models can then sustain foreign lending in equilibrium. Yet, these classic penalties have ambiguous empirical support. 
In this paper, I then take a different perspective, which focuses on the direct consequences of default on the domestic economy to support external debt.

As noted by Broner and Ventura (2006), the unwillingness-to-pay problem depends crucially on the ability of the government to discriminate between domestic and foreign bond holders. Indeed, when selective default on the IFM is not possible, the cost of default is borne also by domestic agents and this reduces the attractiveness of the ex-post opportunistic behavior. In the setup described previously, the non-discrimination assumption has clear-cut implications. Given that a default on government bonds affects the reserve of liquidity of domestic firms and precludes the profitable reinvestment in distressed projects, the government has an ex-post incentive to honor its obligations. This would be the case whenever the cost of a liquidity crisis within the economy exceeds the cost of repaying foreign bond holders.

Assumption 6 The government cannot discriminate between domestic and foreign bond holders.

Assumption 6 has both a theoretical and an empirical underpinning. Suppose that government bonds are held by both domestic entrepreneurs and the IFM, and that agents can trade the bond in a well-functioning secondary market. The latter assumption is crucial to sustain Assumption 6. If bond holders were stuck with the bonds purchased in the primary market, the government would be able perfectly to discriminate among domestics and foreigners in each future date and the latter would never lend to the government in the first place. Instead, when a secondary market for sovereign bonds is in place, the government might not be able to track down the nationality of the ultimate holder of each bond issued at date 0 and such lack of information would prevent a selective default on the bonds held by the IFM. As observed by Broner and Ventura (2006) and Panizza (2008), this informational flaw represents a widespread phenomenon in emerging markets. ${ }^{16}$ The following quote from Reinhart et al. (2003) remarks the same point: "the view that extemal debt is completely separable from domestically issued debt is dead wrong".

Broner et al. (2006) argue that the government has no even the incentive to acquire such information, when secondary markets work perfectly. Indeed, if the government could discriminate among domestic and foreign bond holders, the foreigners could unfold their asset positions by selling the bond to domestics (which would buy the bond at any non-negative discount) and would de facto receive their payment in any future contingency. Then, if the government wants to avoid the repayment of foreigners, it must commit to default on all bond holders indiscriminately (e.g., by not gathering information on secondary market transactions and the ultimate bond holders). By doing so, the government would indeed gain an additional degree of freedom. The next subsection shows that, in the specific case considered in my paper, the government's commitment of non-discriminating among domestics and foreigners introduces the possibility to

\footnotetext{
${ }^{16}$ Panizza (2008) reports that in most emerging countries governments commonly fail to keep track of the large volumes of secondary market transactions and end up with almost no information on the ultimate holders of debt.
} 
choose a contingent repayment policy, which depends on the trade-off between the cost of transferring resources to the IFM and the benefit of preserving domestic private sector's liquidity in any future contingency.

\subsection{Equilibrium with sovereign risk}

Recall now that agents are fully rational. Then, the equilibrium with sovereign risk can be solved by backward induction, starting from date 1 . Let $b$ be the quantity of government bonds held by domestic entrepreneurs, $b^{*}$ the quantity of government bonds held by the IFM and $\theta_{s} \in\{\underline{\theta}, \bar{\theta}\}$ the realization of the aggregate productivity shock. The government behaves strategically and chooses whether to repay the debt in order to maximize the average consumption of domestic agents.

Debt repayment would implicitly transfer resources from domestic taxpayers (the workers) to both domestic bond holders (the entrepreneurs) and foreign bond holders (the IFM). The transfer to domestic entrepreneurs involves only a redistribution within the economy. Given that the government does not care about wealth inequality, such a transfer does not reduce aggregate welfare but improves liquidity provision and the reinvestment of unlucky firms. On the other hand, the transfer to the IFM involves a redistribution of resources away from the economy and, as long as the government does not care about foreigners, it implies a loss of domestic welfare. Then, as the government cannot discriminate among bond holders and selectively default on foreigners, it faces a clear trade-off when choosing whether to repay or not.

In particular, the government repays its debt only when the benefits for the entrepreneurs exceed the costs for the workers, or

$$
(1-\gamma) \frac{1}{2}\left[1+\theta_{s}(A-a)\right] b \geq b^{*}+b
$$

where the left hand side measures the average consumption gain of entrepreneurs when the government repays the bond and the right hand side measures the average consumption loss of workers, in each realization of the aggregate shock $\theta_{s} \cdot{ }^{17}$

\footnotetext{
${ }^{17}$ The left hand side of (9) is obtained from rearranging the following formula,

$$
\begin{aligned}
\Pi_{e=1}-\Pi_{e=0}=(1-\gamma) \frac{1}{2}\{ & {\left.\left[\theta_{s} A k+\rho b+f\right]+\left[\theta_{s}(a k+(A-a) i(e=1))+\rho b+f-i(e=1)\right]\right\}- } \\
& -(1-\gamma) \frac{1}{2}\left\{\left[\theta_{s} A k+f\right]+\left[\theta_{s}(a k+(A-a) i(e=0))+f-i(e=0)\right]\right\}
\end{aligned}
$$

where the first term is the average revenue of entrepreneurs when the government repays the bond $(e=1)$, while the second term is the average revenue of entrepreneurs when the government does not repay $(e=0)$. Then, substitute for $i(e)=e \rho b+f$, where $\rho$ is the interest rate paid on government bonds and is greater than one as long as government bonds feature the risk of a future default. Instead, the right hand side of (9) is the value of taxes that the government collects from domestic workers to repay the bond in $t=1, \tau_{1}=\rho\left(b+b^{*}\right)$.
} 
When the quantity $b^{*}$ of government bonds held by the IFM falls within the interval $\left[\underline{b}^{*}(b), \bar{b}^{*}(b)\right]$, where

$$
\begin{aligned}
& \underline{b}^{*}(b) \equiv\left\{(1-\gamma) \frac{1}{2}[1+\underline{\theta}(A-a)]-1\right\} b, \\
& \bar{b}^{*}(b) \equiv\left\{(1-\gamma) \frac{1}{2}[1+\bar{\theta}(A-a)]-1\right\} b,
\end{aligned}
$$

the government repays the bond in the good state and defaults in the bad state. In the latter case, indeed, aggregate productivity drops and the return on additional investment declines. As a result, the social cost of a liquidity crisis is lower than the cost of repaying foreigners and therefore the government repudiates its debt.

Suppose now that in equilibrium the government actually honors its obligations only in the good state, that is $b^{*} \in\left[\underline{b}^{*}(b), \bar{b}^{*}(b)\right]$. Then,

$$
e=\left\{\begin{array}{lll}
1 & \text { if } \theta_{s}=\bar{\theta} & \text { with prob. } \pi(\bar{\theta}) \\
0 & \text { if } \theta_{s}=\underline{\theta} & \text { with prob. } 1-\pi(\bar{\theta})
\end{array},\right.
$$

where $e \in\{0,1\}$ denotes the repayment choice of the government. The rest of the analysis confirms this initial guess.

Take now a step backward and consider date 0. Given that the government bond now features the possibility of future repudiation, it must include a positive risk premium. In particular, as agents are risk neutral, the government bond must yield

$$
\rho=\frac{1}{\pi(\bar{\theta})}
$$

units of the private good in the good state of date 1 for any unit received at date 0 , where $\pi(\bar{\theta})$ is the probability of the good state. As the repayment of government bonds now depends on the state of the economy, as in (11), and includes a positive risk premium, as in (12), at date 0 the representative entrepreneur foresees that, for any initial choice $\{k, b, f\}$, his final output will be given by

$$
\begin{aligned}
& y_{l}\left(\theta_{s}, e\right)=\theta_{s} A k+e \rho b+f \\
& y_{u}\left(\theta_{s}, e\right)=\theta_{s}(a k+(A-a) i(e))+e \rho b+f-i(e)
\end{aligned}
$$

depending on whether he will be lucky or unlucky, where $i(e) \leq e \rho b+f$. Then, the problem of the representative entrepreneur is now defined by

$$
\Pi(e)=\max _{k, i, b, f} \sum_{\theta_{s} \in\{\bar{\theta}, \underline{\theta}\}} \pi\left(\theta_{s}\right)\left[\frac{y_{l}\left(\theta_{s}, e\right)-r_{l}\left(\theta_{s}, e\right)(k-b-f)}{2}+\frac{y_{u}\left(\theta_{s}, e\right)-r_{u}\left(\theta_{s}, e\right)(k-b-f)}{2}\right],
$$


subject to the maximum reinvestment constraint, $i(e) \leq k$, the resource constraint at date 1 (which is now contingent on the state of the economy as a consequence of the government's default policy), i.e. $i(e) \leq e \rho b+f$, where $b \geq 0$ and $f \geq 0$, and the non-negative profit constraint on IFM's loans,

$$
\sum_{\theta_{s} \in\{\bar{\theta}, \underline{\theta}\}} \pi\left(\theta_{s}\right)\left[\frac{r_{l}\left(\theta_{s}, e\right)+r_{u}\left(\theta_{s}, e\right)}{2}\right] \geq 1
$$

As in the previous section, the entrepreneur's choice is subject to a borrowing constraint, which is now given by

$$
r_{l}\left(\theta_{s}, e\right)(k+b+f) \leq \gamma y_{l}\left(\theta_{s}, e\right) \text { and } r_{u}\left(\theta_{s}, e\right)(k+b+f) \leq \gamma y_{u}\left(\theta_{s}, e\right)
$$

Once again, I ensure that the maximum reinvestment constraint is never binding in equilibrium via Technical Assumption 2. Then, as additional investment is always profitable for the entrepreneur, we can substitute for $i(e)=e \rho b+f$ in both (14) and (16).

\section{Technical assumption 2}

The parameter $\gamma$ satisfies the additional condition:

(iv) $\gamma<\frac{1+\pi}{\frac{A+a}{2}+\pi \frac{1}{2}[1+\bar{\theta}(A-a)]}$.

Before proceeding to the solution of program (14)-(16), it is worth remarking that the representative entrepreneur is no longer indifferent between the government and the foreign bond but he strictly prefers the former. This is a consequence of the procyclical payouts of government bonds, which guarantee a greater liquidity provision when there is a high return from additional investment. In order to show formally this result, let's rearrange (14)-(16) by substituting for (13) and the non-negative profit constraint (15), which is binding in equilibrium. Then, the solution of the entrepreneur's problem solves

$$
\Pi(e)=\max _{k, i, b, f} \sum_{\theta_{s} \in\{\bar{\theta}, \underline{\theta}\}} \pi\left(\theta_{s}\right)\left[\frac{y_{l}\left(\theta_{s}, e\right)+y_{u}\left(\theta_{s}, e\right)}{2}\right]-(k-b-f),
$$

subject to

$$
k+b+f \leq \gamma \sum_{\theta_{s} \in\{\bar{\theta}, \underline{\theta}\}} \pi\left(\theta_{s}\right)\left[\frac{y_{l}\left(\theta_{s}, e\right)+y_{u}\left(\theta_{s}, e\right)}{2}\right] .
$$


Notice now that the expected output from the project can be rearranged as,

$$
\sum_{\theta_{s} \in\{\bar{\theta}, \underline{\theta}\}} \pi\left(\theta_{s}\right)\left[\frac{y_{l}\left(\theta_{s}, e\right)+y_{u}\left(\theta_{s}, e\right)}{2}\right]=[A k+b+f]+[a k+\bar{\theta}(A-a) b+(A-a) f] .
$$

It is easy to see that government and foreign bonds are no longer perfect substitutes. When the entrepreneur is unlucky, indeed, the return on savings in government bonds is greater than the return on savings in foreign bonds as the entrepreneur benefits from receiving a larger payment (due to the risk premium) when the state of the economy is good and the return on additional investment is high. Therefore, when the representative entrepreneur saves in the risky government bond rather than in the foreign risk-less bond, the objective function (17) is shifted upward and the borrowing constraint (18) is looser. As a result, the entrepreneur is unambiguously better off by saving exclusively in the risky government bond.

Maximization of program (17)-(18) then implies the following optimal investment and saving decisions,

$$
k=\bar{k}, \quad b=\frac{\gamma \frac{A+a}{2}-1}{1-\gamma \frac{1}{2}[1+\bar{\theta}(A-a)]} \bar{k} \quad \text { and } \quad f=0 .
$$

Similarly as before, the first condition takes into account that the entrepreneur wants to maximize the expected return on initial investment, which is, by construction, unaffected by the presence of sovereign risk. The second condition, instead, is obtained from the borrowing constraint (18).

The attentive reader could object that the result described by condition (19) crucially depends on the assumed risk neutrality of domestic entrepreneurs. Indeed, if the representative entrepreneur were risk-averse, they would seek to maximize his expected utility rather than the expected output from the project. Then, although saving in the procyclical government bond would raise the project's expected output, the risk-averse entrepreneur would prefer to smooth his future consumption by saving in the acyclical foreign bond. Yet, this statement is not necessarily true when the IFM is risk neutral. ${ }^{18}$ In such a case, the representative entrepreneur will be facing a trade-off when choosing to save in the government or in the foreign bond. On one hand, the higher expected production, obtained by saving in the procyclical government bond, would relax the borrowing constraint (18) and it would consent to store larger reserves of liquidity. On the other hand, the possibility to smooth consumption across future states would bias the entrepreneur's preference towards the foreign bond, as it would increase his expected utility. In the appendix, I show that, when the degree of risk aversion is sufficiently low, condition (19) still holds in equilibrium and domestic firms save exclusively in government bonds.

\footnotetext{
${ }^{18}$ The risk neutrality of the IFM is a standard assumption in the literature. The underlying idea is that the IFM can perfectly diversify the aggregate risk associated with the investment in a small open economy.
} 
Consider now the problem of the benevolent government. As in the perfect commitment case, the government choose public investment, debt issuance and individual taxation in order to maximizes the average utility of domestic agents. Yet, the sovereign risk friction poses a limit on the government's ability to borrow from the IFM. Indeed, the level of external debt must be now compatible with the ex-post incentive to pay of the government.

Notice first that the government can no longer arbitrarily choose to issue short-term or long-term debt. In particular, the government's default is costly only when it involves the repudiation of short-term debt. In this case, indeed, the default dries up domestic liquidity and, as a result, the issuance of both domestic and external debt can be compatible with the ex-post incentive to pay of the government. On the other hand, a default on long-term debt would entail no losses for domestic firms: indeed, the announcement of a default on long-term debt could be postponed until date 2 , when unlucky firms already financed the additional investment (by either pledging as collateral their bond holdings or trading them in secondary markets). ${ }^{19}$ In the equilibrium with sovereign risk, then, the government can issue only short-term debt and repays it by collecting taxes on domestic workers at date 1 (since taxation on entrepreneurs is costly, as discussed in the perfect commitment case).

The problem of the government then involves the choice of the policy $\left\{g, b, b^{*}, \tau(e)\right\}$ that maximizes,

$$
W=\Pi(e)+w+v(g)-\tau(e)
$$

where $\Pi(e)$ is the expected revenue of entrepreneurs, and is now conditional on the government repayment choice, $w$ is the labor income of workers, $v(g)$ is the average utility of domestic agents from the public investment $g$ and $\tau(e)$ denotes the expected value of date 1 taxation on workers, i.e. $\tau(e)=\pi(\bar{\theta}) \rho\left(b+b^{*}\right)$. Beside the government's budget constraint,

$$
g=b+b^{*} \quad \text { and } \quad \tau(e)=b+b^{*}
$$

the government's optimal policy is now subject to the incentive-compatibility constraint,

$$
g \leq b+\bar{b}^{*}(b)
$$

where $b$ is determined by (19) and the external debt ceiling $\bar{b}^{*}(b)$ is defined as in (10). That is, the government can borrow from private agents (namely, domestic entrepreneurs and the IFM) only if they can rationally expect that the public debt will be repaid in at least one state of the economy (the good state).

Supposing that the first-best investment in the public project is incompatible with future repay-

\footnotetext{
${ }^{19}$ Yet, long-term debt could be sustained if the government had some type of short-term commitment (as in Broner et al. (2006)), which allows it to announce at date 1 whether it will repay the debt due at date 2 .
} 
ment, it is possible to show that constraint (22) is binding in equilibrium. Therefore, the equilibrium investment in the public project is given by the following constrained-efficient level,

$$
g=b+\bar{b}^{*}(b)
$$

The government has, indeed, a twofold incentive to borrow up to the debt ceiling $b+\bar{b}^{*}(b)$. On one side, the government can undertake a larger investment in the public project, which enhances the welfare of all domestic agents. On the other side, such a borrowing level would induce a procyclical repayment scheme which benefits domestic entrepreneurs.

\subsection{Discussion}

In spite of its simple structure, this model suggests a number of interesting implications. Most notably, the model shows that external debt can emerge even in absence of "classic" penalties (e.g., trade sanctions and exclusion from international capital markets) or reputational costs (as the model considers a one shot game). Indeed, the prospect of triggering a liquidity crisis in the domestic economy restores the government incentive to repay the debt and thereby its ex-ante ability to borrow from foreigners. In this respect, my paper proposes a mechanism through which external debt can be sustained without any intervention of foreign creditors. In particular, the mechanism considered differs from the ones already discussed in the literature, e.g. Broner and Ventura (2006). ${ }^{20}$ These authors, indeed, consider an endowment economy where default leads to an undesirable redistribution of resources between domestic agents. In my model, instead, sovereign default leads to a disruption of private investment.

Second, the model rationalizes the emergence of liquidity crises in the event of sovereign default. When economic conditions are good (positive aggregate productivity or terms-of-trade shocks), the government wants to transfer resources from taxpayers (the workers) to domestic bondholders (the entrepreneurs) and repays the bond. Although such a transfer is costly since it involves the repayment of foreign bondholders, the cost is more than offset by large returns on firms' reinvestment. On the contrary, when economic conditions are bad (negative aggregate productivity or terms-of-trade shocks), the cocktail of high debt and low investment returns precipitates the economy into a liquidity crisis triggered by sovereign default. The model then suggests that default episodes tend to appear more likely in economies characterized by either volatile business cycle or, if we were to consider the aggregate shock as a terms-of-trade shock, pronounced real exchange rate fluctuations.

Concerning this second point, it is worth remarking that there has been a great deal of discussion in the profession on possible reforms of the international financial architecture in order to avoid

\footnotetext{
${ }^{20}$ Sandleris (2004) proposes a further mechanism through which sovereign default exerts a direct consequence on the domestic private sector.
} 
the social costs associated with recent debt crises in emerging markets. ${ }^{21}$ A classic view in the literature is that default represents the only form of insurance against adverse economic conditions available to sovereigns, despite the fact that it is globally inefficient. ${ }^{22}$ As sovereign contractual arrangements do not allow to issue contingent instruments, governments decide to default during bad times as an indirect way to implement a contingent contract. Yet, default episodes are usually associated with large dead-weight losses, given that the costs on creditors are not fully reflected in the borrower's benefits. Such inefficiency has then stimulated several proposal to improve the effectiveness of bail-out programs which could provide an alternative source of insurance to countries. The same considerations can be extrapolated from the previous model. Yet, in my model, the source of the dead-weight loss is not the imposition of foreign penalties, as usually considered, but it is the result of a domestic liquidity crunch. $^{23}$ As the model suggests that the source of social losses is to be looked for in the liquidity crisis triggered by default and not in foreign penalties, this paper provides a theoretical support for crises resolution policies that refuse to sacrifice domestic claims to service external debt.

\section{Institutional and Policy Reforms}

The results discussed in the previous section depend crucially on the interaction between private capital markets imperfections and sovereign risk, and in particular on the following frictions:

(i) the lack of firms' collateral, as described in Assumption 1;

(ii) the missing market for private insurance, as described in Assumption 2;

(iii) the unwillingness-to-pay problem, as described in Assumptions 5 and 6.

The lack of collateral generates the need for liquidity of domestic firms. Were unlucky firms to be able to guarantee to the IFM a non-negative return on the additional investment $i$, i.e. $\gamma \underline{\theta}(A-a)>1$, they would have no need to accumulate reserves of government bonds. Indeed, unlucky firms would be able to borrow the resources they need (to offset the expenditure shock) in the spot credit market at date 1. As already remarked before, the lack of firms' collateral then makes domestic entrepreneurs willing to insure against the expenditure shock, as they want to avoid a pitfall in the expected revenue from the project.

\footnotetext{
${ }^{21}$ See for instance the last chapter in Sturzenegger and Zettelmeyer (2006).

${ }^{22}$ Tomz and Wright (2007) provide empirical support to this view showing that sovereign defaults occur more often during "bad times".

${ }^{23}$ In general, trade sanctions or capital market exclusion represent a dead-weight welfare loss as they reduce the gains from trade.
} 
The missing market for private insurance implies that domestic entrepreneurs are not able efficiently to insure against the expenditure shock. Indeed, they cannot under-write contingent contracts with the IFM, which promise a positive transfer when the firm is unlucky in exchange for a positive payment when the firm is lucky. Absent contingent contracts and given that borrowing at date 1 is not possible, the only alternative open to entrepreneurs to buffer future shocks is to accumulate reserves of non-contingent securities, which can be deployed in case of need.

Lastly, the unwillingness-to-pay problem, interacted with the two previous frictions, exacerbates the financial instability of the domestic economy, as it introduces the risk of widespread liquidity crises. When choosing whether to honor its debt obligations, the government faces, indeed, a trade-off that depends on the state of the economy. As previously shown, liquidity crises might arise when economic conditions deteriorate and the government chooses opportunistically to default in order to avoid the repayment of foreigners.

The purpose of this section is to discuss the legal and institutional reforms that could improve private liquidity provision and reduce the economy's exposure to government debt. It should be now clear that, in this economy, such reforms would have to deal with each one of the points enumerated above.

Clearly, reforms that raise the value of firms' collateral (e.g. reforms of bankruptcy procedures, improvements in accounting standards, information disclosure) would shift upward the parameter $\gamma$, thereby relaxing the borrowing constraint of domestic entrepreneurs both at the initial investment stage (date 0) and along the production process (date 1). Such reforms would then relax firms' need to hoard liquidity and would ultimately lead to deeper markets for private equities.

However, when the rise of private collateral is not followed by institutional and political reforms that enhance the government's credibility, deeper markets for private equities could crowd out sovereign debt markets. The intuition is the following. As entrepreneurs would have no need to save in government bonds, a default on public debt would have no effect on the additional investment of domestic firms and the government would be able to repudiate its debt at no cost. By foreseeing the risk of an opportunistic behavior by the government, the IFM would refrain from buying public bonds. Such effect on the composition of international capital inflows in the economy would, nevertheless, fade away as soon as the government acquires a credible commitment technology. ${ }^{24}$

\footnotetext{
${ }^{24}$ As discussed in Henry and Lorentzen (2003), the distinction between equity and debt flows is critical to assess the benefits from global financial liberalization. Equity contracts create risk-sharing as they involve procyclical payouts and can therefore lead to balance-of-payment stabilization. Debt contracts, instead, require constant payments regardless of economic conditions and can potentially provoke sudden flows reversals when investors become concerned about either the liquidity or the solvency of the borrower. A prudent international financial architecture should then favor equity flows. Nonetheless, debt flows (with a preponderance of public and publiclyguaranteed debt flows) constitute a prominent share of total capital inflows in developing countries (see for instance Table 4 in Henry (2007)). Therefore, "the critical issue is what distortions in the international financial
} 
Yet, it could be argued that the lack of collateral and the absence of government's commitment, i.e. points (i) and (iii), might also depend on factors not directly related to the improvement of the legal and institutional environment. In particular, there might be technological reasons that avoid the build-up of firms' collateral, e.g. specialization in sectors with low asset tangibility, and political, technological and social reasons that might jeopardize the future solvency of the government, e.g. political instability, excessive reliance on natural resources having volatile returns, social unrest and civil wars. For these reasons, in the following analysis I will maintain the assumptions that the economy suffers from a lack of private collateral and the government's commitment is not credible. Instead, I will focus more specifically on friction (ii), which, arguably, is more closely related to the state of legal institutions in the country.

\subsection{Endogenous insurance provision}

So far, the inability of domestic firms to get insurance from the IFM has been considered as an exogenous feature of the economy. As argued before, this assumption stands on the presence of moral hazard issues on the firm side. This section analyzes the government incentive to improve domestic regulation in order to relax this friction. The ultimate purpose of this analysis is to describe the economic conditions that lead to such reforms.

Suppose that in this economy there exist two types of firms, which I call respectively "good" and "bad". In particular, good firms can obtain insurance from the IFM which commits to provide a contingent credit line when the firm receives an adverse shock (in exchange for an initial payment). The idea is that good firms represents strictly regulated and actively monitored companies where moral hazard issues are negligible. Bad firms, instead, represents poorly regulated companies which are not able to get insurance and therefore must save in non-contingent government bonds in order to buffer future shocks. In addition, the proportion of good firms in the economy is endogenously determined by the government's decision to reform domestic regulation.

Assumption 2' A fraction $\lambda$ of domestic firms (good firms) can enter into state-contingent contracts with the IFM. The remaining fraction of domestic firms (bad firms) cannot enter into state-contingent contracts. The government can costlessly increase the fraction $\lambda$ by improving domestic regulation.

system produce incentives that lead to so much debt and so little equity" (Henry (2007)). A vast macroeconomic literature points the finger to a weak protection of the rights of equity investors in developing countries. Yet, as poor creditor rights protection is usually correlated with low credibility of governments, this argument can account for the low levels of equity flows but it cannot convincingly explain why debt flows are so large (in relative terms). Indeed, the risk of debt repudiation should deter debt flows. The novelty of this paper is then to study how the lack of private collateral shapes the sovereign incentive to repay its debt. In doing so, it can explain why, in countries characterized by a weak legal enforcement, foreign investors substitute equity contracts with debt contracts rather than simply refrain from investing in the country. Whilst in the former case the composition of capital flows changes, as suggested by data, in the latter case total capital inflows would decline without a necessary effect on their composition. 
In choosing the new regulation, the government faces a clear trade-off. On one side, the government can raise the fraction of firms that are able efficiently to insure against adverse shocks. On the other hand, as more firms can insure using contingent insurance contracts rather than hoarding reserves of public bonds, the ex-post incentive to repay of the government declines. The IFM, fearing future defaults, would then stop purchasing bonds from the government, which is forced to forgo the investment in the public project. At some point, however, the return on public investment grows so much that the government has no more incentive to improve domestic regulation.

In order to describe the equilibrium for this new setup, it is convenient to consider a simple case where there is only the idiosyncratic expenditure shock. Hence, throughout this section there are no aggregate productivity shocks and the aggregate productivity $\theta$ is normalized to one. This assumption does not affect the relative revenues of good and bad firms. Indeed, as contingent insurance contracts can be made contingent on the aggregate productivity shock as government bonds (which would be contingent on the realization of aggregate productivity as a result of government's default), the difference between the two types of assets is independent on the presence of the aggregate shock.

Yet, when there are no aggregate shocks, there will be no sovereign default in equilibrium. As private agents can now perfectly foresee the future (i.e., the equilibrium is deterministic), they limit their purchases of public bonds in order to preserves the government's ex-post incentive to honor its obligations. In this case, the interest rate on government bonds is set by the world interest rate and domestic (bad) firms are indifferent between saving in the domestic public debt or saving abroad (as in the perfect commitment case). In this section, though, I focus on the equilibrium in which domestic (bad) firms save only in government bonds (and not in foreign bonds). The implicit assumption, here, is that, as domestic savings in public bonds permit to sustain a positive level of external debt, the government can coordinate domestic entrepreneurs to save exclusively in government bonds.

\subsubsection{Equilibrium}

Let's first derive the expected revenue for a bad firm and a good firm. As the reform raises the number of good firms in the economy, the marginal benefit of the reform is given by the difference between the two revenues.

Consider first a bad firm which can only save in government bonds. As there are no aggregate shocks, there is no sovereign default in equilibrium and it is possible to show that the optimal investment and saving decisions of the representative bad firm are pinned down by condition 
(6). ${ }^{25}$ Substituting for these conditions, the expected revenue of bad firms is equal to

$$
\Pi_{B}=(1-\gamma) \frac{\frac{A+a}{2}-\delta(A-a)}{1-\gamma \delta(A-a)} \bar{k}
$$

where $\delta=\frac{1}{2}\left(1+\frac{1}{A-a}\right)<1$ as $(A-a)>1$.

Consider now a good firm. In this case, the entrepreneur can buy a contingent security that promises a unit of good if the firm receives the expenditure shock. Let $x$ denote the number of securities purchased by the entrepreneur in the initial period. As agents are risk neutral, the price $q$ of the contingent security has to be actuarial fair in equilibrium, i.e. $q=\frac{1}{2}$. Therefore, by borrowing an amount $k+\frac{1}{2} x$ at date 0 , the representative entrepreneur of a good firm can get as final outputs

$$
y_{G l}=A k \quad \text { and } \quad y_{G u}=a k+(A-a) x
$$

where $x \leq k$, depending on being lucky or unlucky. Substituting for (23) into the entrepreneur's problem (3)-(5), the expected revenue of a good firm is given by

$$
\Pi_{G}=(1-\gamma) \frac{\frac{A+a}{2}-(A-a)}{1-\gamma(A-a)} \bar{k}
$$

where the optimal investment and saving decisions are respectively $k=\bar{k}$ and $x=2 \frac{\gamma \frac{A+a}{2}-1}{1-\gamma(A-a)}$. Notice that, as $\gamma>\frac{1}{\frac{A+a}{2}}$, the first order derivative of $\Pi_{B}$ with respect to $\delta$ is positive and therefore,

$$
\Pi_{G}>\Pi_{B}
$$

since $\delta<1$. In addition, the difference in the revenues of good and bad firms is increasing in the expected productivity of domestic projects, i.e. $\frac{A+a}{2}$.

Although the reform raises the expected revenue of domestic firms, the government incentive to improve domestic regulation declines with the number of good firms in the economy. As discussed above, indeed, the reform reduces the ability of the government to borrow (both from domestic and foreign investors) making the public good provision to fall. At some point, then, the cost of increasing the number of good firms in the economy (measured by the marginal return on public goods) exceeds its benefit (measured by the difference between good firms' and bad firms' profits) and the government would stop improving the domestic regulation. In particular, the government chooses the number of good firms $\lambda$ and the policy $\left\{g, b, b^{*}, \tau\right\},{ }^{26}$ in order to

\footnotetext{
${ }^{25}$ Notice that I set $f=0$ in condition (6), as above discussed.

${ }^{26}$ Notice that the government can only issue short-term debt. As discussed in section 3, indeed, a government's default generates a cost for the domestic economy only when it involves the repudiation of short-term debt.
} 
maximize the social welfare function,

$$
W=\lambda \Pi_{G}+(1-\lambda) \Pi_{B}+w+v(g)-\tau,
$$

subject to the budget constraints,

$$
g=b+b^{*} \quad \text { and } \quad \tau=b+b^{*},
$$

and the incentive-compatibility constraint,

$$
g \leq(1-\lambda) b+\bar{b}^{*}((1-\lambda) b)
$$

where $(1-\lambda) b$ is the aggregate demand for public bonds of bad firms and

$$
\bar{b}^{*}((1-\lambda) b) \equiv(1-\lambda)[(1-\gamma) \delta(A-a)-1] b
$$

is the maximum level of borrowing from foreign investors sustainable in equilibrium. Supposing that the incentive-compatibility constraint is binding in equilibrium (i.e. the first best investment is not incentive-compatible), maximization of the social welfare function with respect to $\lambda$ implies the equilibrium conditions,

$$
\begin{aligned}
& \lambda=1-\Lambda v^{\prime-1}\left(1+\Lambda\left(\Pi_{G}-\Pi_{B}\right)\right), \\
& g=(1-\lambda) \Lambda,
\end{aligned}
$$

where $\Lambda=\frac{1}{(1-\gamma) \delta(A-a) b}>0$.

As the function $v(\cdot)$ is strictly increasing and concave, it is easy to see that the government's decision to increase the number of good firms in the economy depends positively on the average productivity of private projects (as $\Pi_{G}-\Pi_{B}$ is increasing in $\frac{A+a}{2}$ ) and negatively on domestic agents' marginal utility from the public good. The model then describes the economic conditions that lead to better regulation. Consider for instance an emerging country with a scarce level of public infrastructures and human capital and highly specialized in small scale labor intensive sectors. Standard growth and trade theories predict large returns on public investment and small returns on private investment in physical capital. In such a case, the government would have almost no incentive to improve domestic regulation as the returns on public investment in both public infrastructures and education are large relative to the benefits from private investment. As ultimate outcome, the domestic financial system would be characterized by a preponderance of public debt instruments and scarce insurance access of domestic firms. On the contrary, in countries characterized by a good supply of public infrastructure and large returns on private projects, 
the benevolent government would more likely undertake reforms that reduce moral hazard issues and enhance more sophisticated form of insurance available to domestic firms.

\section{Sovereign defaults and liquidity crises: some empirical evidence}

As discussed in previous sections, sovereign default triggers a liquidity crisis within the economy. In particular, it dries up the private sector's reserves of liquidity and thus reduces both reinvestment and final output of domestic firms. Although the model takes a representative agent perspective, it is natural to think that firms with larger liquidity needs will experience sharper consequences in the event of default. In this section, I provide cross-country, crossindustry empirical evidence that is suggestive of the mechanism emphasized by the model. More specifically, the empirical strategy consists in using cross-country data on manufacturing sectors to test whether industries highly dependent on external finance and with large working capital needs experience sharper contractions in the event of default. Since the seminal contribution of Rajan and Zingales (1998), scholars have been looking at the performance of industries with different reliance on financial intermediation in order to derive implications on the real effects of cross-country, cross-time variation in financial institutions. In this paper, I apply a similar methodology to inspect whether industries with high liquidity needs and strong dependence on external finance experience a disproportionate output contraction in the event of default, as suggested by the theoretical model.

Nevertheless, it is fair to say that the empirical analysis here performed cannot be considered as a proper test of the model, but rather a way to provide empirical evidence consistent with its predictions. Indeed, there exist alternative theories that predict a disproportional effect of sovereign default on industries that rely on external sources of finance. In particular, if a sovereign default provokes a sudden stop in foreign lending, financially dependent industries would likely suffer the most. In this case, the empirical evidence would be consistent with the prediction of my model, but the mechanism in place would be different from the one I suggest. As commonly recognized, the identification of the exact nature of the costs associated with sovereign default is not an easy task, given that such costs could arise either from direct sanctions, loss of access to international markets or, as here supposed, from an economy-wide liquidity crisis. ${ }^{27}$ One advantage of using the cross-industry variation within each country is that it is possible to control for country-wide characteristics, as for instance the degree of capital account liberalization (and thus the effects captured hold for any level of penetration of foreign financial institutions in the domestic credit market). Yet, although this methodology permits to reduce the omitted variable criticism, the reader should be aware of potential identification pitfalls, as above described.

\footnotetext{
${ }^{27}$ Refer to Sturzenegger and Zettelmeyer (2006) for a survey of the most influential empirical attempts in this respect.
} 
This empirical hypothesis is tested using the dynamic panel data model,

$$
\begin{aligned}
y_{i, c, t}=\alpha_{i, c} & +\lambda_{i, t}+\mu_{c, t}+y_{i, c, t-1}+ \\
& +\sum_{\tau=0}^{\mathrm{T}}\left(\beta_{F, \tau} \text { FinDep }_{i}+\beta_{L, \tau} \text { Liqi }+\beta_{X, \tau} X_{i}\right) \cdot D E F_{c, t-\tau}+\epsilon_{i, c, t},
\end{aligned}
$$

where the $(\log )$ value added in industry $i$ of country $c$ in time $t, y_{i, c, t}$, is fitted using the lagged dependent variable to control for mean reverting dynamics and a set of industry-country, $\alpha_{i, c}$, industry-time, $\lambda_{i, t}$, and country-time, $\mu_{c, t}$, fixed effects to control for additional explanatory variables omitted in the regression. Notice that the average effect of default on manufacturing production is captured by the country-time fixed effect $\mu_{c, t}$. Lastly, the above specification includes a set of interaction terms constructed using a default indicator $D E F_{c, t-\tau}$, which takes a value of one if country $c$ defaulted $\tau$ years ago, and a variety of industry characteristics. In particular, FinDep $i$ is a measure of an industry's dependence on external finance, $L i q_{i}$ is a measure of an industry's need for liquidity and $X_{i}$ is a variable set of additional industry characteristics which is used to check the robustness of the results to the inclusion of further controls. An important aspect of this specification is that both financial dependence and liquidity needs are computed using data on US industries and do not vary across countries. This assumption is standard in the empirical literature that built on Rajan and Zingales (1998). The economic justification for using a country-invariant index based on US data (where financial frictions are arguably negligible) is to isolate technological differences that affect each industry's demand for both external finance and liquidity from country characteristics that affect their supply (as for instance different degrees of financial development). ${ }^{28}$ Furthermore, as long as those technological differences are likely to persist across countries, these US-based indexes are valid proxies for the relative financial needs of industries based in other countries. Given that FinDepi and $L i q_{i}$ take higher values when an industry shows greater financial dependence and higher liquidity needs, negative coefficients on the interaction terms, i.e. $\beta_{F}<0$ and $\beta_{L}<0$, suggest that this industry experiences sharper output losses in the event of default.

\subsection{Econometric methodology}

This subsection describes the econometric methodology applied to estimate equation (24). First, I remove the industry-time effects, $\lambda_{i, t}$ and the country-time effects, $\mu_{c, t}$, by industry-time and country-time differencing prior to estimation, i.e. all instruments and all regressors are differenced by subtracting the mean for each industry and each time period and then by subtracting the mean for each country and each time period. In particular, the average effect of default on all industries in a given country is captured by the country-time effect $\mu_{c, t}$ and therefore does

\footnotetext{
${ }^{28}$ See Rajan and Zingales (1998) for a similar justification.
} 
not appear in the final results. Second, the presence of the lagged dependent variable among regressors affects the consistency of the within estimator used in static panel data. As reviewed in Bond (2002), the standard procedure in dynamic panel data models is then to use a Generalized Method of Moments (GMM) estimator after first-differencing the data (with the exception of the terms interacted with the default dummy in this particular study) in order to eliminate the industry-country fixed effects. This method was first proposed by Holtz-Eakin et al. (1988) and Arellano and Bond (1991). As instruments to set the identifying moment conditions, I use the first lag the lagged dependent variable, taken in levels. Instead, the interaction between the default dummies and the industry characteristics are assumed to be fully exogenous and, to the extent that the model is already over-identified, are not used as instruments. ${ }^{29}$ In addition, a number of statistical tests apply to control the validity of the assumptions on which the GMM difference estimator is based, as suggested by Arellano and Bond. The first is a Sargan test of overidentifying restrictions that tests the validity of the instruments. The second is a test of second-order serial correlation in the error term. Baltagi (1995) (p. 131), indeed, stresses that a crucial assumption to apply this method is that the differenced error term is $\mathrm{MA}(1)$ and therefore its autocorrelation must fade away after the first lag.

\subsection{Data}

Data on manufacturing industries are obtained from the INDSTAT3 2005 database available from the United Nations Industrial Development Organization. The UNIDO database reports annual data for value added in each manufacturing sector at the 3-digit ISIC classification for a broad sample of countries starting from the 1960s. Original data in current US dollars are first converted in constant prices using the US GDP deflator, as reported in the World Bank's World Development Indicators 2006. As reported in the data appendix, I impose some restrictions to the original data in order to reduce measurement errors and sporadic observations. This is a standard procedure in previous studies employing the same database, which tend to be quite noisy.

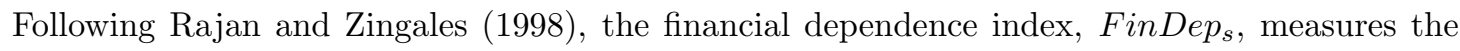
share of investment that is not financed with cash flow from operations. I take the data from Kroszner et al. (2007), who report the Rajan and Zingales' index over the period 1980-1999 on a three-digit ISIC level (rather than a mixture of three-digit and four-digit levels). Based on U.S. publicly listed firm data, this index arguably reflects technological characteristics of industries that are relatively stable across space and time. The original data are, then, normalized such that they range from 0 to 1 , with a higher number indicating greater financial dependence. This eases results readability.

\footnotetext{
${ }^{29}$ In particular, I would like to stress that the sovereign default represents an exogenous shock in the dynamics of sectoral outputs. Indeed, this assumption would fail only if governments repudiate their debt when financially dependent industries perform relatively poorly. Though, this appears to be quite unrealistic since a default possibly reflects a widespread economic downturn rather than a localized sectoral contraction.
} 
The measure of industry liquidity needs, $L i q_{s}$, is defined following Raddatz (2006). His measure is computed as the median ratio of inventories over annual sales of US public manufacturing firms from Compustat, in the same spirit as the Rajan and Zingales's measure of external dependence. This ratio captures the fraction of inventories that can be financed with ongoing revenue and, arguably, is particularly suitable for capturing technological aspects that shape liquidity needs. In particular, firms' needs for working capital raise with the spell of the production process: indeed, the longer the production process the larger is the value of inventories over current sales. Once again, I take the data from Kroszner et al. (2007), who report the Raddatz index over the period 1980-1999 on a three-digit ISIC level (rather than a four-digit level as in the original Raddatz measure). Notice that the correlation between the external dependence index, FinDep ${ }_{s}$, and the liquidity needs index, $L i q_{s}$, is low (0.09) and not statistically different from zero, suggesting that the two index capture different aspects of an industry's financial needs. In particular, the Raddatz measure is specifically designed to capture very short term working capital needs, while the Rajan and Zingales index represents a broader measure of financial needs which does not necessarily distinguish between the short-term and the long-term horizon.

In order to control for additional industry characteristics, $X_{s}$, that might affect industry performance in the event of default, I include in the main specification the interaction terms between the default indicator and two more industry-specific indexes: namely, an index of assets' tangibility, Tang $_{s}$, and an index of export orientation, ExpOr $r_{s, c}$. The former index is computed as the median ratio of fixed assets over total assets for US firms in the period 1980-1999 at the 3-digit ISIC classification and is taken from Kroszner et al. (2007). The latter index is instead measured at the country-industry level, as in

$$
\operatorname{ExpOr}_{s, c}=\frac{1}{T} \sum_{t=1980}^{1980+T} \frac{\text { Exports }_{s, c, t}}{\text { Output }_{s, c, t}} .
$$

In words, $\operatorname{ExpOr}_{s, c}$ is the average share of exports over total sales. Notice that the export orientation index cannot be computed using only US data, as the other industry characteristics. Indeed, the crucial assumption in the Rajan and Zingales methodology is that the rank of US industries based on financial needs is maintained across all countries (if an industry is more financially dependent in the US it is likely to be more financially dependent also in Argentina). Whilst this assumption is reasonable when it refers to financial needs, it is likely to be rejected when we look at industries' export orientation since technological factors do predict that the export orientation of industries in different countries is shaped by country-specific comparative advantages (if a US industry exports more with respect to other industries, this does not imply that the same industry in Argentina will export more than other Argentine industries). The data source used to construct the export orientation index is Nicita and Olarreaga (2001), who report export and import values for each ISIC industry.

Data on default episodes are sourced from the Standard and Poor's sovereign default database, as 
reported in Beers and Chambers (2002). This database includes all sovereign defaults on loans or bonds with private agents between 1975 and 2002, and reports the period during which the debtor government remained in default. The immediate effect of default is captured giving a value of one to the dummy variable in the first year of each default episode. Finally, the resulting sample includes 28 manufacturing sectors in a cross-section of 108 countries over the period 1980-2002, although the sectoral representation can vary across countries and years.

\subsection{Results}

Table 3 reports the one-step first-differenced GMM estimates of (24) where I do not include positive lags for the default indicator (i.e. $\mathrm{T}=0$ ) in order to focus on the instantaneous effects of default. Furthermore, table 3 reports the main estimates for 1980-1990 sample and for the 1990-2002 sample to check the time stability of the key coefficients over the two periods. Notice, first, that the autocorrelation coefficient $\rho$ is statistically significant and pretty stable over the different specifications. A back-of-envelope calculations suggests that temporary shocks to sectoral output are quite persistent over time, with an implied persistency of about three years.

Turning to the interaction between sovereign default and industry characteristics, the point estimates of $\beta_{F}$ and $\beta_{L}$ have negative sign over all specifications and this result suggests that industries with high dependence on external finance and high liquidity needs experience a disproportionate contraction in the event of sovereign default. Yet, the results also show that this effect is statistically significant and robust to the inclusion of additional industry controls only in the sub-period 1990-2002. This result does not imply a rejection of the theoretical model, but, possibly, a stronger support for it. Indeed, a crucial assumption in the model, namely the non-discrimination between foreign and domestic bond holders, suits more realistically the institutional set-up of sovereign debt markets in the 1990s. As noted by Broner and Ventura (2006), during the 1980s most sovereign borrowing was granted by foreign financial institutions in the form of syndicated bank loans, whilst private national financial markets were highly segmented. "This institutional setup clearly facilitates ex-post discrimination, as governments can choose not to pay foreign banks without interfering with domestic asset trade." During the 1990s, instead, many governments in emerging markets started to issue debt in the form of anonymous bonds, which are highly traded in secondary markets. In these economies, governments usually fail to keep track of the large volumes of transaction in public bond secondary market and end up with almost no information of the ultimate holders of debt (Panizza (2008)). Finally, notice that the effect captured by coefficient $\beta_{1}$ is also economically significant, as it implies that, in the first year of a default episode, the level of output in the most financially dependent sector (Transportation equipment) is roughly a 27 percent lower than the output in the least financially dependent one (Tobacco), after controlling for additional industry characteristics. 
Finally, I inspect whether the effect of default on different industries is persistent over time by adding up to 2 lags of for interaction terms between the default indicator and each industry characteristics to the baseline specification (24). The results are reported in table 3. In particular, the results obtained suggest that the disproportional effect of sovereign default on financially dependent industries decays very rapidly, as the coefficient on the lagged interaction terms are never statistically significant.

In conclusion, the evidence show that default episodes are associated with a disproportional output contraction in industries that rely extensively on external sources of finance. In particular, there is no significant evidence suggesting that sovereign default determines a decline in industries where the demand for external finance is specifically targeted to the very short-term. Yet, while the theoretical model suggests that sovereign default might be connected with a widespread credit crunch within the economy, it does not univocally predict whether the consequences of default are different between industries with short or medium term liquidity needs.

\section{Conclusion}

Sovereign debt crises in emerging markets are usually associated with financial turmoil and liquidity crises throughout the economy. This connection is suggested by both anecdotical and empirical evidence. In particular, defaults episodes appear to lead banking crises. However, there is no clear evidence supporting the application of foreign penalties when default occurs.

This paper then proposes a novel mechanism linking sovereign defaults with liquidity and banking crises without any intervention of foreign creditors. The model considers a standard unwillingnessto-pay problem assuming that: (i) the enforcement of private contracts is limited and, as a result, public debt represents a source of liquidity; (ii) the government cannot discriminate between domestic and foreign agents. The model shows that external debt might emerge even in absence of classic penalties imposed by foreign creditors. Indeed, the prospect of triggering a liquidity crisis throughout the economy restores the ex-post incentive to pay of the government. Nonetheless, liquidity crises might arise when economic conditions deteriorate and the government chooses opportunistically to default in order to avoid the repayment of foreign agents.

This paper then contributes to a recent strand of the sovereign debt literature that focuses on the direct consequences of sovereign default on the domestic economy, most notably Broner and Ventura (2006). Yet, the mechanism and, thereby the consequences arising in the event of default, differ from the one highlighted by these authors. In their setup, a sovereign default leads to an undesirable redistribution of resources within the economy. In my model, instead, sovereign default leads to a disruption of private investment. Along different lines, these two papers suggest a remarkable policy implication: as they show that the source of the costs associated with default is to be looked for in the direct consequences on the domestic private sector and not in foreign 
penalties, these papers provide a theoretical underpinning for crises resolution policies that refuse to sacrifice domestic claims to service external debt.

Finally, this paper provides a fully-fledged framework to think about domestic legal and institutional reforms. Different types of reforms are considered and, for each one of them, the implications on international capital flows are remarked. In particular, the model shows that government's incentive to undertake a legal reform is positively related to the average return on private investment and negatively to the return on public investment. The paper then suggests a possible explanation for cross-country and cross-time variation in legal institutions which differs from studies stressing political economy issues. 


\section{References}

Aghion, P., P. Bacchetta, and A. Banerjee (2004). Financial development and the instability of open economies. Journal of Monetary Economics 51(6), 1077-1106.

Aguiar, M. and G. Gopinath (2006). Defaultable debt, interest rates and the current account. Journal of International Economics 69(1), 64-83.

Allen, F. and D. Gale (2004). Financial intermediaries and markets. Econometrica 72(4), 10231061.

Amador, M. (2004). A political model sovereign debt repayment. 2004 Meeting Papers 762, Society for Economic Dynamics.

Arellano, C. (2008). Default Risk and Income Fluctuations in Emerging Economies. American Economic Review 98(3), 690-712.

Arellano, M. and S. Bond (1991). Some tests of specification for panel data: Monte carlo evidence and an application to employment equations. The Review of Economic Studies 58(2), 277-297.

Baltagi, B. H. (1995). Econometric Analysis of Panel Data. eds J. Wiley\&Sons, Chischester.

Beers, D. and J. Chambers (2002). Sovereign Defaults: Moving Higher Again in 2003? Standard and Poor's Research. New York.

Bernanke, B. and M. Gertler (1989). Agency costs, net worth, and business fluctuations. The American Economic Review 79(1), 14-31.

Bernanke, B. S., M. Gertler, and S. Gilchrist (1999). The financial accelerator in a quantitative business cycle framework. In J. B. Taylor and M. Woodford (Eds.), Handbook of Macroeconomics. Elsevier Science.

Bond, S. (2002). Dynamic panel data models: a guide to microdata methods and practice. CeMMAP working papers CWP09/02, Centre for Microdata Methods and Practice, Institute for Fiscal Studies.

Borensztein, E. and U. Panizza (2006). Do sovereign defaults hurt exporters? RES Working Papers 1018, Inter-American Development Bank, Research Department.

Borensztein, E. and U. Panizza (2008). The Cost of Default. IMF Working Papers 08/238, International Monetary Fund.

Broner, F., A. Martin, and J. Ventura (2006). Sovereign Risk and Secondary Markets. Working Papers (Universitat Pompeu Fabra. Departamento de Economía y Empresa) (998), 1.

Broner, F. and J. Ventura (2006). Globalization and risk sharing. Universitat Pompeu Fabra. Mimeo. 
Broner, F. and J. Ventura (2008). Rethinking the effects of financial liberalization. Universitat Pompeu Fabra. Mimeo.

Bulow, J. and K. Rogoff (1989). Sovereign debt: Is to forgive to forget? American Economic Review 79(1), 43-50.

Caballero, R., E. Farhi, and P. Gourinchas (2008). An Equilibrium Model of "Global Imbalances" and Low Interest Rates. The American Economic Review 98(1), 358-393.

Caballero, R. and A. Krishnamurthy (2001). International and domestic collateral constraints in a model of emerging market crises. Journal of Monetary Economics 48(3), 513-548.

Caballero, R. and A. Krishnamurthy (2008). Collective risk management in a flight to quality episode. Journal of Finance 63(5), 2195-2230.

Carlstrom, C. T. and T. S. Fuerst (1997). Agency costs, net worth, and business fluctuations: A computable general equilibrium analysis. American Economic Review 87(5), 893-910.

Chang, R. and A. Velasco (1999). Liquidity crises in emerging markets: Theory and policy. NBER Working Papers 7272, National Bureau of Economic Research, Inc.

Cole, H. L. and P. J. Kehoe (1998). Models of sovereign debt: Partial versus general reputations. International Economic Review 39(1), 55-70.

de la Torre, A. and S. L. Schmukler (2004). Whither latin american capital markets? World Bank Report.

Eaton, J. and R. Fernández (1995). Sovereign debt. Handbooks in Economics (3), 2031-2078.

Eaton, J. and M. Gersovitz (1981). Debt with potential repudiation: Theoretical and empirical analysis. The Review of Economic Studies 48(2), 289-309.

Eichengreen, B., R. Hausmann, and U. Panizza (2003). Currency mismatches, debt intolerance and original sin: Why they are not the same and why it matters. NBER Working Papers 10036, National Bureau of Economic Research, Inc.

Fernandez, R. and R. W. Rosenthal (1990). Strategic models of sovereign-debt renegotiations. Review of Economic Studies 57(3), 331-49.

Gorton, G. and L. Huang (2004). Liquidity, Efficiency, and Bank Bailouts. The American Economic Review 94(3), 455-483.

Grossman, H. I. and J. B. Van Huyck (1988). Sovereign debt as a contingent claim: Excusable default, repudiation, and reputation. American Economic Review 78(5), 1088-97.

Henry, P. (2007). Capital Account Liberalization: Theory, Evidence, and Speculation. Journal of Economic Literature 45(4), 887-935. 
Henry, P. B. and P. L. Lorentzen (2003). Domestic capital market reform and access to global finance: Making markets work. Working Paper 10064, National Bureau of Economic Research.

Holmstrom, B. and J. Tirole (1998). Private and public supply of liquidity. Journal of Political Economy 106(1), 1-40.

Holtz-Eakin, D., W. Newey, and H. S. Rosen (1988). Estimating vector autoregressions with panel data. Econometrica 56(6), 1371-1395.

Hubbard, R. (1998). Capital-Market Imperfections and Investment. Journal of Economic Literature $36(1), 193-225$.

Kaminsky, G. and C. Reinhart (1999). The Twin Crises: The Causes of Banking and Balance of Payments Crises. American Economic Review 89(3), 473-500.

Kiyotaki, N. and J. Moore (1997). Credit cycles. The Journal of Political Economy 105(2), $211-248$.

Kletzer, K. M. and B. D. Wright (2000). Sovereign debt as intertemporal barter. American Economic Review 90(3), 621-639.

Kocherlakota, N. (2000). Creating Business Cycles Through Credit Constraints. Federal Reserve Bank of Minneapolis Quarterly Review 24(3), 2-10.

Kroszner, R., L. Laeven, and D. Klingebiel (2007). Banking crises, financial dependence, and growth. Journal of Financial Economics 84(1), 187-228.

Kumhof, M. (2004). Fiscal crisis resolution: Taxation versus inflation. 2004 Meeting Papers 874, Society for Economic Dynamics.

Kumhof, M. and E. Tanner (2005). Government debt: A key role in financial intermediation. IMF Working Papers 05/57, International Monetary Fund.

Martin, A. (2005). Endogenous credit cycles. Economics Working Papers 916, Department of Economics and Business, Universitat Pompeu Fabra.

Matsuyama, K. (2004). Financial market globalization, symmetry-breaking, and endogenous inequality of nations. Econometrica 72(3), 853-884.

Mendoza, E. (2006). Endogenous Sudden Stops in a Business Cycle Model With Collateral Constraints: A Fisherian Deflation of Tobin's Q. NBER Working Paper.

Mishkin, F. S. (2006). The Next Great Globalization. Princeton, N.J.: Princeton University Press.

Modigliani, F. and M. H. Miller (1958). The cost of capital, corporation finance and the theory of investment. The American Economic Review 48(3), 261-297. 
Nicita, A. and M. Olarreaga (2001). Trade and production, 1976-99. Policy Research Working Paper Series 2701, The World Bank.

Panizza, U. (2008). Domestic and external public debt in developing countries. Debt and Finance Analysis Unit, Division of Globalization and Development Strategies, UNCTAD. Mimeo.

Raddatz, C. (2006). Liquidity needs and vulnerability to financial underdevelopment. Journal of Financial Economics 80(3), 677-722.

Rajan, R. and L. Zingales (2003). The great reversals: the politics of financial development in the twentieth century. Journal of Financial Economics 69(1), 5-50.

Rajan, R. G. and L. Zingales (1998). Financial dependence and growth. American Economic Review 88(3), 559-86.

Reinhart, C., K. Rogoff, and M. Savastano (2003). Debt intolerance. Brookings Papers on Economic Activity (1), 1-75.

Reinhart, V., B. Sack, and J. Heaton (2000). The economic consequences of disappearing government debt. Brookings Papers on Economic Activity 2000(2), 163-220.

Sandleris, G. (2006). Sovereign Defaults: Information, Investment and Credit. Johns Hopkins. Mimeo.

Stein, J. C. (2003). Agency, information and corporate investment. In G. Constantinides, M. Harris, and R. M. Stulz (Eds.), Handbook of the Economics of Finance. Elsevier.

Sturzenegger, F. and J. Zettelmeyer (2006). Debt defaults and lessons from a decade of crises. Cambridge: MIT Press.

Taddei, F. (2004). Liquidity and the allocation of credit: Business cycle, government debt and financial arrangements. Collegio Carlo Alberto. Mimeo.

Tomz, M. and M. Wright (2007). Do countries default in "bad times"? Journal of the European Economic Association 5(2-3), 352-360.

Woodford, M. (1990). Public debt as private liquidity. The American Economic Review 80(2), $382-388$.

Wright, M. (2002). Reputation and sovereign debt. Mimeo. Stanford.

Yue, V. Z. (2005). Sovereign default and debt renegotiation. 2005 Meeting Papers 138, Society for Economic Dynamics. 


\section{A A snapshot of the Argentine crisis}

After being almost fatally wounded by the shock wave of the Mexican Tequila Crisis in 1994-1995, the Argentinean banking system was deeply reformed by the introduction of a new regulatory regime, called BASIC, designed following the international standards in the Basel Accord. As reported by Mishkin (2006) in his recent book The Next Great Globalization, the reform was instigated by concerns raised by depositors' run on domestic banks and the consequent decline in bank lending to non-financial companies which drove the Argentine economy into a recession. The new regime had "strict liquidity requirements, which required banks to hold $20 \%$ of shortterm deposits in safe and liquid assets". Though, from the Basel Accord it inherited "a weighting scheme for measuring bank risk according to which government bonds were classified as being the least risky of all assets that a bank could hold" designed to fit advanced countries better than emerging markets. Thus, at the outset of the 2001 crisis Argentine banks were already major holders of government debt and the banks' exposure grew further when the limits on the share of government bonds in bank reserves were lifted to allow the central government to collocate additional debt: "the banks went along because, with their high interest rates, the bonds would be very profitable if the government avoided default". By then, the stability of the banking system was compromised. When the government announced a temporary suspension of debt payments and, soon after, abandoned the currency board, most firms were declared insolvent on their dollardenominated debts and the strength of bank balance sheets was seriously undermined by large losses in both the defaulted government debt and private loans. That precarious situation was further exacerbated by the subsequent asymmetric pesofication of bank loans and deposits. With banks not granting new loans, businesses dramatically cut back on their spending, aggravating further the economic downturn. While the trigger of the Argentine debt crisis is arguably in four external shocks (namely, the appreciation of the US dollar, the decline in the terms of trade, the Russian crisis and the Brazilian exchange rate crisis), Mishkin's analysis shows that the cost of the government's default was substantially magnified by the destabilization of the internal credit market. 


\section{B Theoretical appendix}

\section{B.1 Precautionary savings and equity markets.}

This section shows formally how the lack of collateral causes an under-supply of private equities in the economy and thereby limits the ability of firms to save the optimal amount of resources. Instead the government intervention, by committing workers' income via taxation, adds to private collateral and expands the supply of securities in the economy.

Let $y_{\gamma}=\gamma \sum_{\theta_{s} \in\{\bar{\theta}, \underline{\theta}\}} \pi\left(\theta_{s}\right)\left[\theta_{s} \frac{A k+a k+(A-a) i}{2}\right]$ denote the maximum number of equities that each entrepreneur can issue at date 0 . Each equity assigns to its holder an ownership right on one unit of the expected production (or equivalently a unit share of production in each state). Given that agents are risk neutral, the price of each equity is then equal to one. In order to finance the initial investment the entrepreneur issues a quantity $\alpha y_{\gamma}=k$ of equities to foreign investors. Then, he trades the remaining quantity $b_{p}=(1-\alpha) y_{\gamma}$ to constitute a portfolio of private equities issued by other firms. Indeed, although the entrepreneur is risk-neutral, he wants to diversify among all firms' equities in order to maximize the value of his portfolio at date 1 and therefore increase the additional reinvestment in his own project. Using symmetry, the value of market portfolio is equal to $b_{p}$. Let

$$
y_{l}\left(\theta_{s}\right)=\theta_{s} A k+b_{p} \quad \text { and } \quad y_{u}\left(\theta_{s}\right)=\theta_{s}(a k+(A-a) i)+b_{p}-i
$$

denote the entrepreneur's final output when he has been lucky or unlucky, and includes the private asset holding $b_{p} \geq 0$. The problem of the representative entrepreneur is then,

$$
\Pi=\max _{k, b_{p}} \sum_{\theta_{s} \in\{\bar{\theta}, \underline{\theta}\}} \pi\left(\theta_{s}\right)\left[\frac{y_{l}\left(\theta_{s}\right)-r_{l}\left(\theta_{s}\right)\left(k+b_{p}\right)}{2}+\frac{y_{u}\left(\theta_{s}\right)-r_{u}\left(\theta_{s}\right)\left(k+b_{p}\right)}{2}\right]
$$

where $r_{l}\left(\theta_{s}\right)\left(k+b_{p}\right)$ and $r_{u}\left(\theta_{s}\right)\left(k+b_{p}\right)$ denote the dividends paid, respectively, by lucky and unlucky entrepreneurs, which are subject to the collateral constraints,

$$
r_{l}\left(\theta_{s}\right)\left(k+b_{p}\right) \leq \gamma y_{l}\left(\theta_{s}\right) \text { and } r_{u}\left(\theta_{s}\right)\left(k+b_{p}\right) \leq \gamma y_{u}\left(\theta_{s}\right)
$$

and must satisfy the non-negative profit constraint on IFM's loans,

$$
\sum_{\theta_{s} \in\{\bar{\theta}, \underline{\theta}\}} \pi\left(\theta_{s}\right)\left[\frac{r_{l}\left(\theta_{s}\right)+r_{u}\left(\theta_{s}\right)}{2}\right] \geq 1
$$

In addition, the entrepreneur's problem is subject to the constraint on the maximum number of 
equities that can be issued at date 0 , that is

$$
k+b_{p} \leq y_{\gamma}
$$

After substituting (26) into (27) and considering that constraint (27) must be binding in equilibrium, the entrepreneur's problem consists in maximizing (25) subject to (28) and the following constraint,

$$
k+b_{p} \leq \gamma \sum_{\theta_{s} \in\{\bar{\theta}, \underline{\theta}\}} \pi\left(\theta_{s}\right)\left[\frac{y_{l}\left(\theta_{s}\right)+y_{u}\left(\theta_{s}\right)}{2}\right] .
$$

Given that $b_{p}>0$, in equilibrium $y_{\gamma}<\gamma \sum_{\theta_{s} \in\{\bar{\theta}, \underline{\theta}\}} \pi\left(\theta_{s}\right)\left[\frac{y_{l}\left(\theta_{s}\right)+y_{u}\left(\theta_{s}\right)}{2}\right]$. Therefore, constraint (29) is never binding in equilibrium and can be omitted. Notice now that the entrepreneur's problem is very similar to problem (3)-(5). It is however subject to a more stringent constraint, i.e. (28). In conclusion, the analysis of this section shows that, when domestic firms save in private equities, they are not able to get the same revenues that they would obtain when they can save in the government bonds. As this follows from the inclusion of constraint (28) in the entrepreneur's problem, this result depends on a shortage of aggregate collateral which generates an under-supply of private securities.

\section{B.2 Sovereign risk and risk aversion}

Suppose that domestic firms are risk-averse and the IFM is risk neutral. Let $U$ define the utility function (over private consumption) of domestic entrepreneurs, where

$$
U=\sum_{\theta_{s} \in\{\bar{\theta}, \underline{\theta}\}} \pi\left(\theta_{s}\right) \frac{u\left(c_{l}\left(\theta_{s}, e\right)\right)+u\left(c_{u}\left(\theta_{s}, e\right)\right)}{2},
$$

where $u(\cdot)$ is increasing and concave, $c_{l}\left(\theta_{s}, e\right)=y_{l}\left(\theta_{s}, e\right)-r_{l}\left(\theta_{s}\right)(k+b+f)$ denotes the consumption of lucky entrepreneurs for each realization of $\theta_{s}, c_{u}\left(\theta_{s}, e\right)=y_{u}\left(\theta_{s}, e\right)-r_{u}\left(\theta_{s}\right)(k+b+f)$ denotes the consumption of lucky entrepreneurs, $y_{l}\left(\theta_{s}, e\right)$ and $y_{u}\left(\theta_{s}, e\right)$ are defined as in (13), and

$$
\sum_{\theta_{s} \in\{\bar{\theta}, \underline{\theta}\}} \pi\left(\theta_{s}\right)\left[\frac{r_{l}\left(\theta_{s}\right)+r_{u}\left(\theta_{s}\right)}{2}\right] \geq 1,
$$

given that the IFM is risk-neutral and competitive. Then, the problem of the representative entrepreneur is defined by the maximization of (30), subject to (31) and the borrowing con- 
straint,

$$
r_{l}\left(\theta_{s}\right)(k+b+f) \leq \gamma y_{l}\left(\theta_{s}\right) \text { and } r_{u}\left(\theta_{s}\right)(k+b+f) \leq \gamma y_{u}\left(\theta_{s}\right) .
$$

Given that constraint (31) is binding in equilibrium, the above program can be solved by maximizing the following Lagrangean,

$$
\begin{aligned}
\mathbb{L}=\sum_{\theta_{s} \in\{\bar{\theta}, \underline{\theta}\}} \pi\left(\theta_{s}\right) \frac{u\left(c_{l}\left(\theta_{s}, e\right)\right)+u\left(c_{u}\left(\theta_{s}, e\right)\right)}{2}+ \\
+\nu\left[\gamma \sum_{\theta_{s} \in\{\bar{\theta}, \underline{\theta}\}} \pi\left(\theta_{s}\right)\left[\frac{y_{l}\left(\theta_{s}, e\right)+y_{u}\left(\theta_{s}, e\right)}{2}\right]-(k+b+f)\right] .
\end{aligned}
$$

Notice, first, that the optimal initial investment $k$ is still equal to $\bar{k}$. Indeed, as initial investment is, by construction, profitable for both the entrepreneur and the IFM, the entrepreneur, by investing up to $\bar{k}$, can increase both his expected utility and he can relax the borrowing constraint (32). That is, he faces no trade-off when choosing the initial investment $k$. Let's, then, focus exclusively on the first order conditions with respect to $b$ and $f$, which are respectively:

$$
\begin{aligned}
& \frac{\pi(\bar{\theta})}{2}\left\{\left(\rho-r_{l}(\bar{\theta})\right) u^{\prime}\left(c_{l}(\bar{\theta}, 1)\right)+\left(\rho \bar{\theta}(A-a)-r_{u}(\bar{\theta})\right) u^{\prime}\left(c_{u}(\bar{\theta}, 1)\right)\right\}- \\
& \quad-\frac{\pi(\underline{\theta})}{2}\left\{r_{l}(\underline{\theta}) u^{\prime}\left(c_{l}(\underline{\theta}, 0)\right)+r_{u}(\underline{\theta}) u^{\prime}\left(c_{u}(\underline{\theta}, 0)\right)\right\}+\lambda\left(\frac{1+\bar{\theta}(A-a)}{2}-1\right)=0, \\
& \frac{\pi(\bar{\theta})}{2}\left\{\left(1-r_{l}(\bar{\theta})\right) u^{\prime}\left(c_{l}(\bar{\theta}, 1)\right)+\left(\bar{\theta}(A-a)-r_{u}(\bar{\theta})\right) u^{\prime}\left(c_{u}(\bar{\theta}, 1)\right)\right\}- \\
& \quad+\frac{\pi(\underline{\theta})}{2}\left\{\left(1-r_{l}(\underline{\theta})\right) u^{\prime}\left(c_{l}(\underline{\theta}, 0)\right)+\left(\underline{\theta}(A-a)-r_{u}(\underline{\theta})\right) u^{\prime}\left(c_{u}(\underline{\theta}, 0)\right)\right\}+\lambda\left(\frac{1+(A-a)}{2}-1\right)=0 .
\end{aligned}
$$


Let's rearrange the above conditions as follows:

$$
\begin{gathered}
\frac{\pi(\bar{\theta})}{2}\left\{\left(1-r_{l}(\bar{\theta})\right) u^{\prime}\left(c_{l}(\bar{\theta}, 1)\right)+\left(\bar{\theta}(A-a)-r_{u}(\bar{\theta})\right) u^{\prime}\left(c_{u}(\bar{\theta}, 1)\right)\right\}-\frac{\pi(\underline{\theta})}{2}\left\{r_{l}(\underline{\theta}) u^{\prime}\left(c_{l}(\underline{\theta}, 0)\right)+r_{u}(\underline{\theta}) u^{\prime}\left(c_{u}(\underline{\theta}, 0)\right)\right\}+ \\
+\frac{1-\pi(\bar{\theta})}{2}\left\{u^{\prime}\left(c_{l}(\bar{\theta}, 1)\right)+\bar{\theta}(A-a) u^{\prime}\left(c_{u}(\bar{\theta}, 1)\right)\right\}+\lambda\left(\frac{1+\bar{\theta}(A-a)}{2}-1\right)=0, \\
\frac{\pi(\bar{\theta})}{2}\left\{\left(1-r_{l}(\bar{\theta})\right) u^{\prime}\left(c_{l}(\bar{\theta}, 1)\right)+\left(\bar{\theta}(A-a)-r_{u}(\bar{\theta})\right) u^{\prime}\left(c_{u}(\bar{\theta}, 1)\right)\right\}-\frac{\pi(\underline{\theta})}{2}\left\{r_{l}(\underline{\theta}) u^{\prime}\left(c_{l}(\underline{\theta}, 0)\right)+r_{u}(\underline{\theta}) u^{\prime}\left(c_{u}(\underline{\theta}, 0)\right)\right\}+ \\
+\frac{\pi(\underline{\theta})}{2}\left\{u^{\prime}\left(c_{l}(\underline{\theta}, 1)\right)+\underline{\theta}(A-a) u^{\prime}\left(c_{u}(\underline{\theta}, 1)\right)\right\}+\lambda\left(\frac{1+(A-a)}{2}-1\right)=0,
\end{gathered}
$$

Notice now that the first rows of equation (35) and (36) are identical and let $\kappa$ denote their value. In addition, recall that $1-\pi(\bar{\theta})=\pi(\underline{\theta})$. Finally, the representative entrepreneur's problem admits an interior solution for $b$ and $f$, i.e. $b \geq 0$ and $f \geq 0$, provided the following condition is satisfied:

$$
\frac{\kappa+\frac{\pi(\underline{\theta})}{2}\left\{u^{\prime}\left(c_{l}(\bar{\theta}, 1)\right)+\bar{\theta}(A-a) u^{\prime}\left(c_{u}(\bar{\theta}, 1)\right)\right\}}{\kappa+\frac{\pi(\underline{\theta})}{2}\left\{u^{\prime}\left(c_{l}(\underline{\theta}, 1)\right)+\underline{\theta}(A-a) u^{\prime}\left(c_{u}(\underline{\theta}, 1)\right)\right\}}=\frac{\frac{1+\bar{\theta}(A-a)}{2}-1}{\frac{1+(A-a)}{2}-1}
$$

On the contrary, when the left hand side of (37) exceeds the right hand side, $b>0$ and $f=0$, and viceversa. Notice now that the left hand side is decreasing in the degree of concavity of the function $u(\cdot)$, or the degree of risk aversion of domestic entrepreneurs. Given that the left hand side is strictly greater than the right hand side (so $b>0$ and $f=0$ as showed in the main text), there exists at least one concave utility function such that the left hand side is strictly greater than the right hand side and the entrepreneur chooses to save in the procyclical government bond, despite being risk averse. Nonetheless, as the degree of risk aversion of domestic entrepreneurs increases, the optimal saving choice of domestic firms would involve only the purchase of foreign riskless bonds. 


\section{Data Description}

Log Value Added $(y)$. Log of value added in US dollars at the 3-digit ISIC classification for manufacturing sectors. Data are sourced from the UNIDO INDSTAT 2005 database. Original data are deflated using the GDP deflator in United States from the World Bank's World Development Indicators 2006 CD-ROM.

Default Dummy $(D E F)$. Dummy variable taking a value one in the first year of a default episode. Data on default episodes are sourced from the Standard and Poor's sovereign default database, as reported in Beers and Chambers (2002). This database includes all sovereign defaults on loans or bonds with private agents between 1975 and 2002, and reports the period during which the debtor government remained in default.

Financial Dependence (FinDep). An index constructed as the median share of capital expenditures not financed with the cash flow from operations (capital expenditures minus cash flow from operation divided by capital expenditures) by US-based, publicly listed firms. The index is sourced from Kroszner et al. (2007), who provide a 3-digit ISIC based reclassification of the data originally constructed by Rajan and Zingales (1998) for a mixture of 3-digit and 4-digit ISIC sectors. The data refer to the period 1980-1999 and, originally, range from -1.14 (Tobacco) to 0.72 (Transport equipment), with a higher number indicating greater financial dependence. To ease statical inference, I normalize the index such that it ranges from 0 to 1.

Liquidity NeEds ( $L i q)$. An index constructed as the median ratio of inventories over total sales for US-based, publicly listed firms. This index has been initially proposed by Raddatz (2006) to measure industrys financial needs that focuses on short-term liquidity needs. The data are sourced from Kroszner et al. (2007), who compute the Raddatz index for the 3-digit ISIC manufacturing sectors. The data refer to the 1980s and, originally, range from 0.07 (Tobacco) to 0.72 (Plastic Products), with a higher number indicating greater financial dependence. To ease statical inference, I normalize the index such that it ranges from 0 to 1.

TANGibility $\left(\right.$ Tang $\left._{s}\right)$. An index constructed as the median ratio of net property, plant and equipment to total assets by US-publicly listed firms during the period 1980-1999 in each 3-digit ISIC manufacturing sector. The data are sourced from Kroszner et al. (2007). The original data range from 0.12 to 0.62 , and are normalized such that they range from 0 to 1 .

ExpOr $r_{s, c}$. An index of export orientation computed as the average share of exports over total sales for each industry in each country included in the sample. The data source used to construct the export orientation index is Nicita and Olarreaga (2001), who report export and import values for each ISIC industry. 


\section{C.1 Deletion criteria}

First, I delete all observations for which the data for value added are either missing or negative. Second, given that the initial panel is unbalanced, I remove all sector-country-year observations with data for less than 5 years. This reduces the within estimator's sensitivity to isolated observations in the panel. Third, I exclude all country-year pairs reporting data for less than 10 sectors, in order to guarantee sufficient within country-year variation in the interaction between financial dependence and default (captured by the coefficient $\beta_{1}$ ). The same criterium is applied in Borensztein and Panizza (2006). Fourth, I drop those observations for which the growth rate of value added fall in the top and bottom 1 percent of the distribution. This is a common strategy in order to limit the noise created by outliers. 
Table 1: Default episodes in the sample

\begin{tabular}{|c|c|}
\hline Country & Default year \\
\hline Argentina & 1989 \\
\hline Bolivia & 1986 \\
\hline Bolivia & 1989 \\
\hline Chile & 1983 \\
\hline Costa Rica & 1981 \\
\hline Costa Rica & 1984 \\
\hline Cuba & 1982 \\
\hline Dominican Republic & 1981 \\
\hline Ecuador & 1982 \\
\hline Egypt, Arab Rep. & 1984 \\
\hline El Salvador & 1981 \\
\hline Ghana & 1987 \\
\hline Guatemala & 1986 \\
\hline Honduras & 1981 \\
\hline Jamaica & 1981 \\
\hline Jamaica & 1987 \\
\hline Jordan & 1989 \\
\hline Kuwait & 1990 \\
\hline Madagascar & 1981 \\
\hline Madagascar & 1986 \\
\hline Malawi & 1982 \\
\hline Mexico & 1982 \\
\hline Morocco & 1986 \\
\hline Nigeria & 1982 \\
\hline Panama & 1983 \\
\hline Panama & 1987 \\
\hline Peru & 1983 \\
\hline Philippines & 1983 \\
\hline Poland & 1981 \\
\hline Senegal & 1981 \\
\hline Senegal & 1990 \\
\hline Serbia and Montenegro & 1983 \\
\hline South Africa & 1985 \\
\hline South Africa & 1989 \\
\hline Tanzania & 1984 \\
\hline Turkey & 1982 \\
\hline Uruguay & 1983 \\
\hline Uruguay & 1987 \\
\hline Uruguay & 1990 \\
\hline Venezuela, RB & 1983 \\
\hline Venezuela, RB & 1990 \\
\hline
\end{tabular}


Table 2: Estimation Results

\begin{tabular}{|c|c|c|c|c|c|}
\hline & (1) & $(2)$ & (3) & (4) & (5) \\
\hline & 1980-1990 & 1980-1990 & 1990-2002 & 1990-2002 & 1990-2002 \\
\hline$y_{s, c, t-1}$ & $\begin{array}{c}0.373^{* * *} \\
(0.054)\end{array}$ & $\begin{array}{c}0.375^{* * *} \\
(0.054)\end{array}$ & $\begin{array}{c}0.455^{* * *} \\
(0.059)\end{array}$ & $\begin{array}{c}0.454^{* * *} \\
(0.059)\end{array}$ & $\begin{array}{c}0.483^{* * *} \\
(0.055)\end{array}$ \\
\hline$D E F_{c, t} \cdot F_{i n D e p}$ & $\begin{array}{c}-0.094 \\
(0.070)\end{array}$ & $\begin{array}{c}-0.097 \\
(0.071)\end{array}$ & $\begin{array}{c}-0.208^{*} \\
(0.117)\end{array}$ & $\begin{array}{c}-0.196^{*} \\
(0.117)\end{array}$ & $\begin{array}{c}-0.275^{*} \\
(0.148)\end{array}$ \\
\hline$D E F_{c, t} \cdot L i q_{s}$ & $\begin{array}{c}-0.092^{*} \\
(0.052)\end{array}$ & $\begin{array}{c}-0.069 \\
(0.069)\end{array}$ & $\begin{array}{c}-0.053 \\
(0.088)\end{array}$ & $\begin{array}{c}-0.126 \\
(0.115)\end{array}$ & $\begin{array}{c}-0.093 \\
(0.125)\end{array}$ \\
\hline$D E F_{c, t} \cdot \operatorname{Tang}_{s}$ & & $\begin{array}{c}0.033 \\
(0.065)\end{array}$ & & $\begin{array}{l}-0.115 \\
(0.116)\end{array}$ & $\begin{array}{c}-0.044 \\
(0.143)\end{array}$ \\
\hline$D E F_{c, t} \cdot \operatorname{ExpOr} r_{s, c}$ & & & & & $\begin{array}{l}-0.078 \\
(0.160)\end{array}$ \\
\hline $1^{\text {st }}$ autocorr. & 0.00 & 0.00 & 0.00 & 0.00 & 0.00 \\
\hline $2^{\text {nd }}$ autocorr. & 0.00 & 0.00 & 0.42 & 0.42 & 0.27 \\
\hline Sargan test & 0.00 & 0.00 & 0.21 & 0.21 & 0.12 \\
\hline Obs. & 15406 & 15406 & 15605 & 15605 & 12828 \\
\hline
\end{tabular}

***, ${ }^{* *},{ }^{*}$ represent significance at $1 \%, 5 \%$, and $10 \%$, respectively. The table reports the onestep first-differenced GMM estimator for the main specifications for the 1980-1990 and the 1990-2002 samples. The set of instruments includes the first lag of the lagged dependent variable. Country-time effects are removed by country-time differencing prior to estimation. Sector-country fixed effects are removed by first differencing. Heteroskedasticity-consistent standard errors are reported within parenthesis. $1^{\text {st }}$ autocorr. and $2^{\text {nd }}$ autocorr. are autocorrelation tests on the estimation residuals. $p$-values for the asymptotic $N(0,1)$ distribution are reported. The Sargan test of over-identifying restrictions is based on a two-step GMM estimation. $p$-values for the asymptotic $\chi^{2}$ distribution are reported. 
Table 3: Estimation Results

\begin{tabular}{|c|c|c|c|c|c|}
\hline & (1) & $(2)$ & (3) & (4) & $(5)$ \\
\hline & 1980-1990 & 1980-1990 & 1990-2002 & 1990-2002 & 1990-2002 \\
\hline$y_{s, c, t-1}$ & $\begin{array}{c}0.379^{* * *} \\
(0.054)\end{array}$ & $\begin{array}{c}0.378^{* * *} \\
(0.054)\end{array}$ & $\begin{array}{c}0.450^{* * *} \\
(0.059)\end{array}$ & $\begin{array}{c}0.451^{* * *} \\
(0.059)\end{array}$ & $\begin{array}{c}0.480 * * * \\
(0.055)\end{array}$ \\
\hline$D E F_{c, t} \cdot F i n D e p_{s}$ & $\begin{array}{l}-0.094 \\
(0.069)\end{array}$ & $\begin{array}{l}-0.097 \\
(0.070)\end{array}$ & $\begin{array}{c}-0.225^{* *} \\
(0.113)\end{array}$ & $\begin{array}{l}-0.213^{*} \\
(0.113)\end{array}$ & $\begin{array}{c}-0.303^{* *} \\
(0.140)\end{array}$ \\
\hline$D E F_{c, t-1} \cdot F i n D e p_{s}$ & $\begin{array}{l}0.102^{*} \\
(0.061)\end{array}$ & $\begin{array}{l}0.100^{*} \\
(0.061)\end{array}$ & $\begin{array}{c}0.086 \\
(0.115)\end{array}$ & $\begin{array}{c}0.077 \\
(0.116)\end{array}$ & $\begin{array}{c}0.163 \\
(0.148)\end{array}$ \\
\hline$D E F_{c, t-2} \cdot F i n D e p_{s}$ & $\begin{array}{r}-0.127^{*} \\
(0.072)\end{array}$ & $\begin{array}{l}-0.120^{*} \\
(0.072)\end{array}$ & $\begin{array}{c}0.099 \\
(0.097)\end{array}$ & $\begin{array}{c}0.097 \\
(0.097)\end{array}$ & $\begin{array}{c}0.116 \\
(0.109)\end{array}$ \\
\hline$D E F_{c, t} \cdot L i q_{s}$ & $\begin{array}{l}-0.096^{*} \\
(0.051)\end{array}$ & $\begin{array}{l}-0.076 \\
(0.067)\end{array}$ & $\begin{array}{l}-0.050 \\
(0.085)\end{array}$ & $\begin{array}{l}-0.122 \\
(0.112)\end{array}$ & $\begin{array}{l}-0.091 \\
(0.123)\end{array}$ \\
\hline$D E F_{c, t-1} \cdot L i q_{s}$ & $\begin{array}{c}0.002 \\
(0.049)\end{array}$ & $\begin{array}{c}0.015 \\
(0.067)\end{array}$ & $\begin{array}{l}-0.020 \\
(0.085)\end{array}$ & $\begin{array}{c}0.037 \\
(0.097)\end{array}$ & $\begin{array}{c}0.056 \\
(0.106)\end{array}$ \\
\hline$D E F_{c, t-2} \cdot L i q_{s}$ & $\begin{array}{l}-0.085 \\
(0.055)\end{array}$ & $\begin{array}{l}-0.131^{*} \\
(0.078)\end{array}$ & $\begin{array}{l}-0.002 \\
(0.077)\end{array}$ & $\begin{array}{c}0.007 \\
(0.104)\end{array}$ & $\begin{array}{c}0.015 \\
(0.106)\end{array}$ \\
\hline$D E F_{c, t} \cdot \operatorname{Tang}_{s}$ & & $\begin{array}{c}0.030 \\
(0.064)\end{array}$ & & $\begin{array}{l}-0.112 \\
(0.114)\end{array}$ & $\begin{array}{l}-0.033 \\
(0.141)\end{array}$ \\
\hline$D E F_{c, t-1} \cdot \operatorname{Tang}_{s}$ & & $\begin{array}{c}0.019 \\
(0.063)\end{array}$ & & $\begin{array}{c}0.087 \\
(0.101)\end{array}$ & $\begin{array}{c}0.059 \\
(0.114)\end{array}$ \\
\hline$D E F_{c, t-2} \cdot \operatorname{Tang}_{s}$ & & $\begin{array}{l}-0.068 \\
(0.071)\end{array}$ & & $\begin{array}{c}0.013 \\
(0.097)\end{array}$ & $\begin{array}{l}-0.011 \\
(0.102)\end{array}$ \\
\hline$D E F_{c, t} \cdot \operatorname{ExpO} r_{s, c}$ & & & & & $\begin{array}{l}-0.051 \\
(0.155)\end{array}$ \\
\hline$D E F_{c, t-1} \cdot \operatorname{ExpO} r_{s, c}$ & & & & & $\begin{array}{l}-0.019 \\
(0.143)\end{array}$ \\
\hline$D E F_{c, t-1} \cdot \operatorname{ExpO} r_{s, c}$ & & & & & $\begin{array}{l}-0.081 \\
(0.117)\end{array}$ \\
\hline $\begin{array}{l}1^{\text {st }} \text { autocorr. } \\
2^{\text {nd }} \text { autocorr. } \\
\text { Sargan test }\end{array}$ & $\begin{array}{l}0.00 \\
0.00 \\
0.00\end{array}$ & $\begin{array}{l}0.00 \\
0.00 \\
0.00\end{array}$ & $\begin{array}{l}0.00 \\
0.52 \\
0.23\end{array}$ & $\begin{array}{l}0.00 \\
0.53 \\
0.22\end{array}$ & $\begin{array}{l}0.00 \\
0.26 \\
0.13\end{array}$ \\
\hline Obs. & 15406 & 15406 & 15605 & 15605 & 12828 \\
\hline
\end{tabular}

